\title{
Position of the American Dietetic Association and Dietitians of Canada: Vegetarian diets
}

\section{ABSTRACT}

It is the position of the American Dietetic Association and Dietitians of Canada that appropriately planned vegetarian diets are healthful, nutritionally adequate, and provide health benefits in the prevention and treatment of certain diseases. Approximately $2.5 \%$ of adults in the United States and $4 \%$ of adults in Canada follow vegetarian diets. A vegetarian diet is defined as one that does not include meat, fish, or fowl. Interest in vegetarianism appears to be increasing, with many restaurants and college foodservices offering vegetarian meals routinely. Substantial growth in sales of foods attractive to vegetarians has occurred, and these foods appear in many supermarkets. This position paper reviews the current scientific data related to key nutrients for vegetarians, including protein, iron, zinc, calcium, vitamin $\mathrm{D}$, riboflavin, vitamin $\mathrm{B}-12$, vitamin $\mathrm{A}, \mathrm{n}-3$ fatty acids, and iodine. A vegetarian, including vegan, diet can meet current recommendations for all of these nutrients. In some cases, use of fortified foods or supplements can be helpful in meeting recommendations for individual nutrients. Well-planned vegan and other types of vegetarian diets are appropriate for all stages of the life cycle, including during pregnancy, lactation, infancy, childhood, and adolescence. Vegetarian diets offer a number of nutritional benefits, including lower levels of saturated fat, cholesterol, and animal protein as well as higher levels of carbohydrates, fiber, magnesium, potassium, folate, and antioxidants such as vitamins $\mathrm{C}$ and $\mathrm{E}$ and phytochemicals. Vegetarians have been reported to have lower body mass indices than nonvegetarians, as well as lower rates of death from ischemic heart disease; vegetarians also show lower blood cholesterol levels; lower blood pressure; and lower rates of hypertension, type 2 diabetes, and prostate and colon cancer. Although a number of federally funded and institutional feeding programs can accommodate vegetarians, few have foods suitable for vegans at this time. Because of the variability of dietary practices among vegetarians, individual assessment of dietary intakes of vegetarians is required. Dietetics professionals have a responsibility to support and encourage those who express an interest in consuming a vegetarian diet. They can play key roles in educating vegetarian clients about food sources of specific nutrients, food purchase and preparation, and any dietary modifications that may be necessary to meet individual needs. Menu planning for vegetarians can be simplified by use of a food guide that specifies food groups and serving sizes. J Am Diet Assoc. 2003;103:748-765.

\section{POSITION STATEMENT}

It is the position of the American Dietetic Association and Dietitians of Canada that appropriately planned vegetarian diets are healthful, nutritionally adequate, and provide health benefits in the prevention and treatment of certain diseases.

\section{VEGETARIANISM IN PERSPECTIVE}

A vegetarian is a person who does not eat meat, fish, or fowl or products containing these foods. The eating patterns of vegetarians may vary considerably. The lacto-ovo-vegetarian eating pattern is based on grains, vegetables, fruits, legumes, seeds, nuts, dairy products, and eggs but excludes meat, fish, and fowl. The lacto-vegetarian excludes eggs as well as meat, fish, and fowl. The vegan, or total vegetarian, eating pattern is similar to the lacto-vegetarian pattern, with the additional exclusion of dairy and other animal products. Even within these patterns, considerable variation may exist in the extent to which animal products are avoided.

People choosing macrobiotic diets are frequently identified as following a vegetarian diet. The macrobiotic diet is based largely on grains, legumes, and vegetables. Fruits, nuts, and seeds are used to a lesser extent. Some people following a macrobiotic diet are not truly vegetarian because they use limited amounts of fish. Some "self-described" vegetarians, who are not vegetarians at all, will eat fish, chicken, or even meat $(1,2)$. Some research studies have identified these "self-described" vegetarians as semivegetarians and have defined semivegetarian as occasional meat eaters who predominately practice a vegetarian diet (3) or those who eat fish and poultry but less than 1 time per week (4). Individual assessment is required to accurately evaluate the nutritional quality of the diet of a vegetarian or someone who says that they are vegetarian.

Common reasons for choosing a vegetarian diet include health considerations, concern for the environment, and animal welfare factors $(5,6)$. Vegetarians also cite economic reasons, ethical considerations, world hunger issues, and religious beliefs as their reasons for following their chosen eating pattern.

\section{Consumer Trends}

In 2000 , approximately $2.5 \%$ of the US adult population (4.8 million people) consistently followed a vegetarian diet and affirmed that they never ate meat, fish, or poultry (7). Slightly less than $1 \%$ of those polled were vegans (7). According to this poll, vegetarians are most likely to live on the east or west coast, in large cities, and to be female. Approximately $2 \%$ of 6 - to 
17-year-old children and adolescents in the United States are vegetarians, and around $0.5 \%$ of this age group are vegan (8). According to a 2002 survey (9), about 4\% of Canadian adults are vegetarian; this represents an estimated 900,000 people. Factors that may affect the number of vegetarians in the United States and Canada in the future include an increased interest in vegetarianism and the arrival of immigrants from countries where vegetarianism is commonly practiced (10). Twenty to $25 \%$ of adults in the United States report that they eat 4 or more meatless meals weekly or "usually or sometimes maintain a vegetarian diet," suggesting an interest in vegetarianism (11). Additional evidence for the increased interest in vegetarianism includes the emergence of animal rights/ethics courses on college and university campuses; the proliferation of Web sites, magazines and newsletters, and cookbooks with a vegetarian theme; and the public's attitude toward ordering a vegetarian meal when eating away from home. More than 5\% of those surveyed in 1999 said they always order a vegetarian meal when they eat out; close to 60\% "sometimes, often, or always" order a vegetarian item at a restaurant (12).

Restaurants have responded to this interest in vegetarianism. The National Restaurant Association reports that 8 out of 10 restaurants in the United States with table service offer vegetarian entrees (13). Fast-food restaurants are beginning to offer salads, veggie burgers, and other vegetarian options. Many college students consider themselves vegetarians. In response to this, most university foodservices offer vegetarian options (14).

There has also been a growth in professional interest in vegetarian nutrition; the number of articles in the scientific literature related to vegetarianism has increased from less than 10 articles per year in the late 1960s to 76 articles per year in the 1990s (15). In addition, the main focus of the articles is changing. Twenty-five or more years ago, articles primarily had themes questioning the nutritional adequacy of vegetarian diets. More recently, the theme has been the use of vegetarian diets in the prevention and treatment of disease. More articles feature epidemiological studies, and fewer reports are case studies and letters to the editor (15).

There is a growing appreciation for the benefits of plantbased diets, defined as diets that include generous amounts of plant foods and limited amounts of animal foods. The American Institute for Cancer Research and the World Cancer Research Fund call for choosing predominantly plant-based diets rich in a variety of vegetables and fruits, legumes, and minimally processed starchy staple foods and limiting red meat consumption, if red meat is eaten at all (16). The American Cancer Society recommends choosing most food from plant sources (17). The American Heart Association recommends choosing a balanced diet with an emphasis on vegetables, grains, and fruits (18), and the Heart and Stroke Foundation of Canada recommends using grains and vegetables instead of meat as the centerpiece of meals (19). The Unified Dietary Guidelines developed by the American Cancer Society, the American Heart Association, the National Institutes of Health, and the American Academy of Pediatrics call for a diet based on a variety of plant foods, including grain products, vegetables, and fruits to reduce risk of major chronic diseases (20).

\section{New Product Availability}

The US market for vegetarian foods (foods like meat analogs, nondairy milks, and vegetarian entrees that directly replace meat or other animal products) was estimated to be $\$ 1.5$ billion in 2002 , up from $\$ 310$ million in 1996 (21). This market is expected to nearly double by 2006 to $\$ 2.8$ billion (21). Canadian sales of meat analogs more than tripled between 1997 and 2001 (22).

The ready availability of new products, including fortified foods and convenience foods would be expected to have a marked impact on nutrient intake of vegetarians. Fortified foods such as soymilks, meat analogs, juices, and breakfast cereals can add substantially to vegetarians' intakes of calcium, iron, zinc, vitamin B-12, vitamin D, and riboflavin. Vegetarian convenience foods including veggie burgers and veggie dogs, frozen entrees, meals in a cup, and soymilk can make it much simpler to be a vegetarian today than in the past.

Vegetarian foods are readily available, both in supermarkets and in natural foods stores. About half of vegetarian foods volume is sold through supermarkets and about half through natural foods stores (21). Three-fourths of soymilk sales take place in supermarkets (21).

\section{Public Policy Statements and Vegetarian Diets}

The United States Dietary Guidelines (23) state, "Vegetarian diets can be consistent with the Dietary Guidelines for Americans, and meet Recommended Dietary Allowances for nutrients." They give recommendations on meeting nutrient requirements for those who choose to avoid all or most animal products. Some have said that implementation of the Dietary Guidelines can best be achieved by use of vegetarian and plantrich diets (24). National food guides include some vegetarian options. Foods commonly eaten by vegetarians such as legumes, tofu, soyburgers, and soymilk with added calcium are included in a table accompanying the USDA's Food Guide Pyramid (23). Canada's Food Guide to Healthy Eating can be used by lacto and lacto-ovo-vegetarians (25). Health Canada has stated that well-planned vegetarian diets are supportive of good nutritional status and health (26).

\section{HEALTH IMPLICATIONS OF VEGETARIANISM}

Vegetarian diets offer a number of advantages, including lower levels of saturated fat, cholesterol, and animal protein and higher levels of carbohydrates, fiber, magnesium, boron, folate, antioxidants such as vitamins $\mathrm{C}$ and $\mathrm{E}$, carotenoids, and phytochemicals (27-30). Some vegans may have intakes for vitamin B-12, vitamin D, calcium, zinc, and occasionally riboflavin that are lower than recommended $(27,29,31)$.

\section{NUTRITION CONSIDERATIONS FOR VEGETARIANS}

\section{Protein}

Plant protein can meet requirements when a variety of plant foods is consumed and energy needs are met. Research indicates that an assortment of plant foods eaten over the course of a day can provide all essential amino acids and ensure adequate nitrogen retention and use in healthy adults, thus complementary proteins do not need to be consumed at the same meal (32).

Estimates of protein requirements of vegans vary, depending to some degree on diet choices (33). A recent metaanalysis of nitrogen balance studies found no significant difference in protein needs due to the source of dietary protein $(34,35)$. Based primarily on the lower digestibility of plant proteins, other groups have suggested that protein requirements of vegans may be increased by $30 \%$ to $35 \%$ for infants up to the age of 2 years, $20 \%$ to $30 \%$ for 2 - to 6 -year-old children, and $15 \%$ to $20 \%$ for those 6 years and older, in comparison with those of nonvegetarians (36).

The quality of plant proteins varies. Based on the protein 
digestibility corrected amino acid score (PDCAAS), which is the standard method for determining protein quality, isolated soy protein can meet protein needs as effectively as animal protein, whereas wheat protein eaten alone, for example, may be 50\% less usable than animal protein (37). Nutrition care professionals should be aware that protein needs might be higher than the RDA in vegetarians whose dietary protein sources are mainly those that are less well digested, such as some cereals and legumes.

Cereals tend to be low in lysine, an essential amino acid. This may be relevant when evaluating diets of individuals who do not consume animal protein sources and are relatively low in protein (35). Dietary adjustments such as the use of more beans and soy products in place of other protein sources that are lower in lysine or an increase in dietary protein from all sources can ensure an adequate intake of lysine.

Although some vegan women have protein intakes that are marginal, typical protein intakes of lacto-ovo-vegetarians and of vegans appear to meet and exceed requirements (29). Athletes can also meet their protein needs on plant-based diets $(38,39)$.

\section{Iron}

Plant foods contain only nonheme iron, which is more sensitive than heme iron to both inhibitors and enhancers of iron absorption. Inhibitors of iron absorption include phytate; calcium; teas, including some herb teas; coffee; cocoa; some spices; and fiber (40). Vitamin $\mathrm{C}$ and other organic acids found in fruits and vegetables can enhance iron absorption and can help to reduce effects of phytate (41-43). Studies show that iron absorption would be significantly reduced if a diet were to be high in inhibitors and low in enhancers. Recommended iron intakes for vegetarians are 1.8 times those of nonvegetarians because of lower bioavailability of iron from a vegetarian diet (44).

The main inhibitor of iron absorption in vegetarian diets is phytate. Because iron intake increases as phytate intake increases, effects on iron status are somewhat less than might be expected. Fiber appears to have a minor effect on iron absorption $(45,46)$. Vitamin C, consumed at the same time as the iron source, can help to reduce the inhibitory effects of phytate $(42,43)$, and some research links high vitamin C intake to improved iron status $(47,48)$. The same is true for organic acids in fruits and vegetables (41). The higher intakes of vitamin $\mathrm{C}$ and of vegetables and fruits by vegetarians can favorably impact iron absorption (2). Some food preparation techniques such as soaking and sprouting beans, grains, and seeds can hydrolyze phytate (49-51) and may improve iron absorption $(42,51,52)$. Leavening of breads hydrolyzes phytate and enhances iron absorption (49-51,53,54). Other fermentation processes, such as those used to make soy foods like miso and tempeh, may also make iron more available (55), although not all research supports this. Whereas many studies of iron absorption have been short term, there is evidence that adaptation to low intakes takes place over the longer term and involves both increased absorption and decreased losses $(56,57)$. It is likely that iron needs will depend on the make up of the overall diet and be significantly lower for some vegetarians than for others.

Studies typically show iron intake by vegans to be higher than that of lacto-ovo-vegetarians and of nonvegetarians, and most studies show iron intake by lacto-ovo-vegetarians to be higher than that of nonvegetarians (29). Iron sources are shown in the Table. Incidence of iron deficiency anemia among vegetarians is similar to that of nonvegetarians $(29,31,58)$. Although vegetarian adults have lower iron stores than nonveg- etarians, their serum ferritin levels are usually within the normal range (58-62).

\section{Zinc}

Because phytate binds zinc, and animal protein is believed to enhance zinc absorption, total zinc bioavailability appears to be lower on vegetarian diets (63). Also, some vegetarians have diets that are significantly below recommended intakes for zinc $(27,29,64,65)$. Although overt zinc deficiency has not been seen in Western vegetarians, the effects of marginal intakes are poorly understood (66). Zinc requirements for vegetarians whose diets are high in phytate may exceed the RDA (44). Zinc sources are shown in the Table.

Compensatory mechanisms may help vegetarians adapt to lower intakes of zinc $(65,67)$. Some food preparation techniques, such as soaking and sprouting beans, grains, and seeds as well as leavening bread, can reduce binding of zinc by phytate and increase zinc bioavailability $(49,50,68)$.

\section{Calcium}

Calcium is present in many plant foods and fortified foods (see Table). Low-oxalate greens (bok choy, broccoli, Chinese/Napa cabbage, collards, kale, okra, turnip greens) provide calcium with high bioavailability (49\% to $61 \%$ ), in comparison with calcium-set tofu, fortified fruit juices, and cow's milk (bioavailability in the range of $31 \%$ to $32 \%$ ) and with fortified soymilk, sesame seeds, almonds, and red and white beans (bioavailability of $21 \%$ to $24 \%$ ) (69-71). Figs and soy foods such as cooked soybeans, soy nuts, and tempeh provide additional calcium. Calcium-fortified foods include fruit juices, tomato juice, and breakfast cereals. Thus, various food groups contribute dietary calcium $(72,73)$. Oxalates present in some foods can greatly reduce calcium absorption, so vegetables that are very high in these compounds, such as spinach, beet greens, and Swiss chard, are not good sources of usable calcium despite their high calcium content. Phytate may also inhibit calcium absorption. However, some foods with high contents of both phytate and oxalate, such as soy foods, still provide well-absorbed calcium (71). Factors that enhance calcium absorption include adequate vitamin $\mathrm{D}$ and protein.

Calcium intakes of lacto-vegetarians are comparable with or higher than those of nonvegetarians $(74,75)$, whereas intakes of vegans tend to be lower than both groups and often below recommended intakes $(27,31,71,75)$. Diets high in sulfur-containing amino acids may increase losses of calcium from bone. Foods with a relatively high ratio of sulfur-containing amino acids to protein include eggs, meat, fish, poultry, dairy products, nuts, and many grains. There is some evidence that the impact of sulfur-containing amino acids is only important with low calcium intakes. Excessive sodium intake may also promote calcium losses. In addition, some studies show that the ratio of dietary calcium to protein is more predictive of bone health than calcium intake alone. Typically, this ratio is high in lacto-ovo-vegetarian diets and favors bone health, whereas vegans have a calcium to protein ratio that is similar to or lower than that of nonvegetarians $(71,76)$.

All vegetarians should meet the recommended intakes for calcium, established for their age group by the Institute of Medicine (77). This can be accomplished, in nonpregnant, nonlactating adults, by consuming at least 8 servings per day of foods that provide $10 \%$ to $15 \%$ of the Adequate Intake (AI) for calcium, as indicated in the Vegetarian Food Guide Pyramid and Vegetarian Food Guide Rainbow $(72,73)$. Adjustments for 
Table

Vegetarian food sources of nutrients

\section{Nutrient}

Amount per serving

\section{Iron}

Soyfoods

Soybeans, cooked, 1/2 c (125 mL)

Soybeans, dry roasted, (soy nuts), 1/4 c (60 mL)

Soymilk $1 / 2 \mathrm{c}(125 \mathrm{~mL})$

Tempeh, $1 / 2$ c (83 g)

Tofu, firm, 1/2 c (126 g)

Veggie "meats," fortified, $1 \mathrm{oz}(28 \mathrm{~g})$

$\longleftarrow-m g \longrightarrow$

Legumes (cooked, 1/2 c/125 mL)

Adzuki beans

Baked beans, canned, vegetarian

Black beans

Chickpeas, garbanzo beans

Great northern beans

Kidney beans

Lentils

Lima beans

Navy beans

Pinto beans

Nuts, peanuts, seeds, and their butters

Almonds, $1 / 4 \mathrm{c}(60 \mathrm{~mL})$

Cashews, $1 / 4$ c $(60 \mathrm{~mL})$

Peanut butter, 2 tbsp $(30 \mathrm{~mL})$

Peanuts, dry roast, $1 / 4 \mathrm{c}(60 \mathrm{~mL})$

Pumpkin and squash seeds, dried, 1/4 c $(60 \mathrm{~mL})$

Sesame tahini, 2 tbsp $(30 \mathrm{~mL})$

Sunflower seeds, toasted, $1 / 4 \mathrm{c}(60 \mathrm{~mL})$

Breads, cereals, and grains

Barley, pearled, cooked, 1/2 c (125 mL)

Cereal, ready-to-eat, fortified, $1 \mathrm{oz}(28 \mathrm{~g})$

Cream of Wheat, cooked, $1 / 2 \mathrm{c}(125 \mathrm{~mL})$

Oatmeal, instant, fortified, cooked, 1/2 c (125 mL)

Oatmeal, regular, quick or instant, cooked, $1 / 2 \mathrm{c}(125 \mathrm{~mL})$

Quinoa, cooked, 1/2 c (125 mL)

Wheat germ, 2 tbsp (14 g)

Whole wheat or white enriched bread, 1 slice $(28 \mathrm{~g})$

Fruits (dried, 1/4 c/60 mL)

Apricots

Currants

Figs

Prunes

Raisins

Vegetables (cooked, 1/2 c/125 mL unless indicated otherwise)

Bok choy (Chinese cabbage, pak choi)

Broccoli

1.0

Green or yellow beans

Kale

Mung bean sprouts

Mushrooms

Potato, baked, with skin, 1 medium (173 g)

Tomato juice

Turnip greens

Blackstrap molasses, $1 \mathrm{tbsp}(15 \mathrm{~mL})$

\section{Zinc}

Soyfoods

Soybeans, cooked, $1 / 2 \mathrm{c}(125 \mathrm{~mL})$

Soybeans, dry roasted, $1 / 2 \mathrm{c}(60 \mathrm{~mL})$

Soymilk, $1 / 2 \mathrm{c}(125 \mathrm{~mL})$

Soymilk, fortified, $1 / 2 \mathrm{c}(125 \mathrm{~mL})$

Tempeh, $1 / 2$ c (83 g)

Tofu, firm, $1 / 2$ c (126 g)

Veggie "meats," fortified, 1 oz (28 g) 
Table cont'd

Vegetarian food sources of nutrients

\section{Nutrient}

Amount per serving

Legumes (cooked, 1/2 c/125 mL)

Adzuki beans

Baked beans, canned, vegetarian

Black beans

Chickpeas, garbanzo beans

Great northern beans

Kidney beans

Lima beans

Lentils

Navy beans

$\longleftrightarrow-m g \longrightarrow$

Nuts, peanuts, seeds, and their butters

Almonds, $1 / 4 \mathrm{c}(60 \mathrm{~mL})$

2.3

Cashews, $1 / 4 \mathrm{c}(60 \mathrm{~mL})$

Peanut butter, 2 tbsp $(30 \mathrm{~mL})$

Peanuts, dry roast, $1 / 4 \mathrm{c}(60 \mathrm{~mL})$

Pumpkin and squash seeds, dried, 1/4 c $(60 \mathrm{~mL})$

Sesame tahini, 2 tbsp $(30 \mathrm{~mL})$

Sunflower seeds, toasted, 1/4 c (60 mL)

Breads, cereals, and grains

Barley, pearled, cooked, 1/2 c (125 mL)

Cereal, ready-to-eat, fortified, $1 \mathrm{oz}(28 \mathrm{~g})$

Quinoa, cooked, 1/2 c (125 mL)

0.6

Wheat germ, 2 tbsp (14 g)

Whole wheat bread, 1 slice $(28 \mathrm{~g})$

Vegetables (cooked, 1/2 cup/125 mL)

Mushrooms

Peas

Dairy foods and eggs

Cow's milk, 1/2 c (125 mL)

Cheddar cheese, $3 / 4$ oz (21 g)

1.0

Egg, large, $1(50 \mathrm{~g})$

Yogurt, $1 / 2 \mathrm{c}(125 \mathrm{~mL})$

Calcium

\section{Soyfoods}

Cultured soy yogurt, fortified, $1 / 2 \mathrm{c}(125 \mathrm{~mL})$

Soybeans, cooked, $1 / 2 \mathrm{c}(125 \mathrm{~mL})$

Soybeans, dry roasted, (soy nuts), 1/4 c (60 mL)

Soybeans, green, $1 / 2 \mathrm{c}(125 \mathrm{~mL})$

Soymilk, fortified, $1 / 2 \mathrm{c}(125 \mathrm{~mL})$

Tofu, firm, calcium-set, $1 / 2$ c (126 g)

Tempeh, $1 / 2 \mathrm{c}(83 \mathrm{~g})$

Legumes (cooked, 1/2 c/125 mL)

Black beans

Chickpeas, garbanzo beans

Great northern or navy beans

Pinto beans

Vegetarian baked beans

Nuts, seeds and their butters

Almonds, $1 / 4 \mathrm{c}(60 \mathrm{~mL})$

Almond butter, 2 tbsp $(30 \mathrm{~mL})$

Sesame tahini, 2 tbsp $(30 \mathrm{~mL})$

Breads, cereals, and grains

Cereal, ready-to-eat, fortified, $1 \mathrm{oz}$ (28 g)

Fruits

Figs, dried, 5

Orange, 1 large

Orange juice, fortified, $1 / 2 \mathrm{c}(125 \mathrm{~mL})$

Vegetables (cooked, $1 \mathrm{c} / 250 \mathrm{~mL}$ )

Bok choy (Chinese cabbage, pak choi)

Broccoli

Collard greens

Kale

Kale, Scotch

Mustard greens

Okra

Turnip greens 
Table cont'd

Vegetarian food sources of nutrients

\section{Nutrient}

Amount per serving

Other foods

Blackstrap molasses, 1 tbsp (15 mL)

$\longleftarrow m g$ 172

Dairy products

Cow's milk, 1/2 c (125 mL)

Cheddar cheese, 3/4 oz (21 g)

137-158

153

Yogurt, plain, 1/2 c (125 mL)

137-230

\section{Vitamin D}

Cereals, ready-to-eat, fortified, $1 \mathrm{oz}(28 \mathrm{~g})$

Egg yolk, large, 1 (17 g)

Cow's milk, fortified, 1/2 c (125 mL)

Soymilk or other nondairy milk, fortified, 1/2 c (125 mL)

Riboflavin

Almonds, 1/4 c (60 mL)

Cereal, ready-to-eat, fortified, $1 \mathrm{oz}(28 \mathrm{~g})$

Cow's milk, whole, $2 \%$ or skim, $1 / 2$ c (125 mL)

Yogurt, 1/2 c (125 mL)

Egg, large, 1 (50 g)

Mushrooms, cooked, 1/2 c (125 mL)

Nutritional yeast miniflakes, $1 \mathrm{tbsp}(3 \mathrm{~g})$

Soymilk, fortified, $1 / 2 \mathrm{c}(125 \mathrm{~mL})$

\section{Vitamin B-12}

Cereals, ready-to-eat, fortified, $1 \mathrm{oz}(28 \mathrm{~g})$

Cow's milk, 1/2 c (125 mL)

Egg, large, 1 (50 g)

Nutritional yeast (Red Star Vegetarian Support Formula), miniflakes, 1 tbsp (3 g)

Soymilk or other nondairy milks, fortified, 1/2 c (125 mL)

Veggie "meats," fortified, $1 \mathrm{oz}(28 \mathrm{~g})$

\section{Linolenic acid}

Canola oil, 1 tbsp (15 mL)

Flaxseed, ground, 1 tbsp (15 mL)

Flaxseed oil, 1 tsp $(5 \mathrm{~mL})$

Soybean oil, 1 tbsp (15 mL)

Soybeans, cooked, 1/2 c (125 mL)

Tofu, $1 / 2 \mathrm{c}(126 \mathrm{~g})$

Walnuts, $1 / 4$ c (60 mL)

Walnut oil, 1 tbsp (15 mL)

\begin{tabular}{|c|}
\hline $\begin{array}{c}137-158 \\
153 \\
137-230\end{array}$ \\
\hline $\begin{array}{c}\longleftarrow m c g- \\
0.5-1 \\
0.6 \\
1.2-1.3 \\
0.5-1.5\end{array}$ \\
\hline $\begin{array}{c}\leftarrow g \\
0.3 \\
0.2-1.7 \\
0.2 \\
0.3 \\
0.6 \\
0.2 \\
1.9 \\
0.2\end{array}$ \\
\hline $\begin{array}{c}m c g- \\
0.6-6.0 \\
0.4-0.5 \\
0.5 \\
1.5 \\
0.4-1.6 \\
0.5-1.2\end{array}$ \\
\hline $\begin{array}{c}\leftarrow g \\
\leftarrow 1.3-1.6 \\
1.9-2.2 \\
2.7 \\
0.9 \\
1.0 \\
0.7 \\
2.7 \\
1.4-1.7\end{array}$ \\
\hline
\end{tabular}

NOTE. Sources: Package information and data from US Department of Agriculture, Agricultural Research Service, 2002; USDA Nutrient Database for Standard

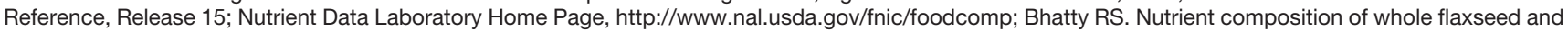
flaxseed meal. In: Cunnane SC, Thompson LU, eds. Flaxseed and Human Nutrition. Champaign, IL: AOCS Press; 1995:22-42.

other stages of the life cycle are available $(72,73)$. Many vegans may find that it is easier to meet needs if fortified foods or supplements are included (69-71,78).

\section{Vitamin D}

Vitamin D status depends on sunlight exposure and intake of vitamin D fortified foods or supplements. Sun exposure to the face, hands, and forearms for 5 to 15 minutes per day during the summer at the 42nd latitude (Boston) is believed to provide sufficient amounts of vitamin D for light-skinned people (79). Those with dark skin require longer exposure (79). Sun exposure may be inadequate for those living in Canada and at northern latitudes in the United States, especially in winter months, for those in smoggy regions, and for those whose sun exposure is limited. Furthermore, infants, children, and older adults synthesize vitamin D less efficiently $(77,79,80)$. Sunscreen can interfere with vitamin D synthesis, although reports are inconsistent and may depend on amount of sunscreen applied $(79,81,82)$. Low vitamin D levels and reduced bone mass have been observed in some vegan populations at northern latitudes who did not use supplements or fortified foods, particularly children following macrobiotic diets and adult Asian vegetarians (29,83-85).

Foods that are fortified with vitamin D include cow's milk, some brands of soymilk and rice milk, and some breakfast cereals and margarines (see Table). Vitamin D3 (cholecalciferol) is of animal origin, whereas vitamin D2 (ergocalciferol) is a form acceptable to vegans. Vitamin D2 may be less bioavailable than vitamin D3, which could raise the requirements of vegetarians who depend on D2 supplements to meet vitamin D needs (86). If sun exposure and intake of fortified foods are insufficient, vitamin D supplements are recommended.

\section{Riboflavin}

Some studies have shown vegans to have lower intakes of riboflavin, compared with nonvegetarians; however, clinical riboflavin deficiency has not been observed $(27,29,31)$. In addition to foods shown in the Table, foods that provide about $1 \mathrm{mg}$ of riboflavin per serving are asparagus, bananas, beans, broccoli, figs, kale, lentils, peas, seeds, sesame tahini, sweet potatoes, tofu, tempeh, wheat germ, and enriched bread (87). 


\section{Vitamin B-12}

Sources of vitamin B-12 that are not derived from animals include B-12 fortified foods (such as some brands of soymilk, breakfast cereals, and nutritional yeast) or supplements (see Table). Unless fortified, no plant food contains significant amounts of active vitamin B-12. Foods such as sea vegetables and spirulina may contain vitamin B-12 analogs; neither these nor fermented soy products can be counted on as reliable sources of active vitamin B-12 $(29,88)$. Lacto-ovo-vegetarians can get adequate vitamin B-12 from dairy foods and eggs if these foods are consumed regularly.

Vegetarian diets are typically high in folic acid, which can mask the hematological symptoms of vitamin B-12 deficiency. Therefore, some cases of deficiency may not be detected until after the onset of neurological symptoms (89). If there are concerns about vitamin B-12 status, serum homocysteine, methylmalonic acid, and holotranscobalamin II should be measured (90).

A regular source of vitamin B-12 is crucial for pregnant and lactating women and for breastfed infants if the mother's diet is not supplemented. Infants born to vegan mothers whose diets lack reliable sources of this vitamin are at especially high risk of deficiency. Maternal vitamin B-12 intake and absorption during pregnancy appear to have a more important influence on vitamin B-12 status of the infant than do maternal vitamin B-12 stores (91). Because $10 \%$ to $30 \%$ of those over the age of 50 years, regardless of the type of diet they follow, lose their ability to digest the protein-bound form of the vitamin that is present in eggs, dairy, and other animal products, all people over the age of 50 should use vitamin B-12 supplements or fortified foods (92).

Studies indicate that some vegans and other vegetarians do not regularly consume reliable sources of vitamin B-12 and that this is reflected in less than adequate vitamin B-12 status $(27,29,88,89,93-95)$. It is essential that all vegetarians use a supplement, fortified food, dairy products, or eggs to meet recommended intakes of vitamin B-12 (see Table).

Absorption is most efficient when small amounts of vitamin B-12 are consumed at frequent intervals. This could be achieved through use of fortified foods. When less than $5 \mu \mathrm{g}$ of crystalline vitamin B-12 is consumed at one time, approximately $60 \%$ is absorbed, whereas $\leq 1 \%$ of a dose of $500 \mu \mathrm{g}$ or higher of vitamin B-12 is absorbed (92).

\section{Vitamin A/Beta Carotene}

Because preformed vitamin A is found only in animal foods, vegans get all of their vitamin A from conversion of dietary carotenoids, particularly beta carotene. Research suggests that absorption of beta carotene from plant foods is less efficient than previously believed $(44,96)$. This suggests that vegans intake of vitamin A is about half of what previous studies have suggested, and intake by lacto-ovo-vegetarians may be $25 \%$ lower than previously shown. Despite this, vegetarians have been reported to have higher serum carotenoid levels than nonvegetarians (29). Vitamin A requirements can be met with the inclusion of three servings per day of deeply yellow or orange vegetables, leafy green vegetables, or fruits that are rich in beta carotene (apricots, cantaloupe, mango, pumpkin). Cooking increases beta carotene absorption, as does the addition of small amounts of fat to meals (97). Chopping and pureeing vegetables may also increase bioavailability $(98,99)$.

\section{N-3 Fatty Acids}

Whereas vegetarian diets are generally rich in n-6 fatty acids (especifically linoleic acid), these diets can be low in n-3 fatty acids, resulting in an imbalance that can inhibit production of the physiologically active long chain n-3 fatty acids, eicosapentaenoic acid (EPA), and docosahexaenoic acid (DHA). Diets that do not include fish, eggs, or generous amounts of sea vegetables generally lack direct sources of EPA and DHA. Recently, vegan sources of DHA derived from microalgae have become available as supplements in nongelatin capsules. Algae sources of DHA have been shown to positively affect blood levels of DHA and of EPA through retroconversion (100).

Most studies show vegetarians, and particularly vegans, to have lower blood levels of EPA and DHA than nonvegetarians (101-104). The new Dietary Reference Intakes recommend intakes of 1.6 and 1.1 grams of $\alpha$-linolenic acid per day for men and women, respectively. These are designated as AIs rather than RDAs. These recommendations assume some intake of long-chain n-3 fatty acids and may not be optimal for vegetarians who consume little if any DHA and EPA (35). The Joint World Health Organization/Food Agriculture Organization (WHO/FAO) Expert Consultation on Diet, Nutrition and the Prevention of Chronic Diseases (105) recommends 5\% to 8\% of calories from n-6 fatty acids and 1\% to $2 \%$ of calories from n-3 fatty acids. Based on an energy intake of 2,000 kcal per day, this would suggest a daily intake of 2.2 to 4.4 grams of n-3 fatty acids. Those who do not receive a preformed source of EPA and DHA require increased amounts of n-3 fatty acids. The recommended ratio of n-6 to n-3 fatty acids is in the range of $2: 1$ to $4: 1$ (106-109).

It is recommended that vegetarians include good sources of $\alpha$-linolenic acid in their diet $(106,110)$. These would include foods like flaxseed and flaxseed oil (see Table). Those with increased requirements (eg, pregnant and lactating women or those with diseases associated with poor essential fatty acid status) or those at risk for poor conversion (eg, people with diabetes) may benefit from direct sources of long-chain n-3 fatty acids, such as DHA-rich microalgae $(100,106,111)$.

\section{lodine}

Some studies suggest that vegans who do not consume iodized salt may be at risk for iodine deficiency; this appears to be particularly true for those living in iodine-poor areas $(29,112,113)$. Bread can be a source of iodine because some dough stabilizers contain iodine. In the United States, about $50 \%$ of the general population uses iodized salt, whereas, in Canada, all table salt is fortified with iodine. Sea salt and kosher salt are generally not iodized nor are salty seasonings such as tamari. Concern has been raised about vegetarian diets that include foods, such as soybeans, cruciferous vegetables, and sweet potatoes, that contain natural goitrogens. However, these foods have not been associated with thyroid insufficiency in healthy people provided iodine intake is adequate. The adult $\mathrm{RDA}$ for iodine is easily met by one-half teaspoon of iodized salt daily (44). Some vegetarians may have very high intakes of iodine because of consumption of sea vegetables.

\section{VEGETARIANISM THROUGHOUT THE LIFE CYCLE}

Well-planned vegan, lacto-vegetarian, and lacto-ovo-vegetarian diets are appropriate for all stages of the life cycle, including pregnancy and lactation. Appropriately planned vegan, lactovegetarian, and lacto-ovo-vegetarian diets satisfy nutrient needs of infants, children, and adolescents and promote normal 
growth $(36,114,115)$. Vegetarian diets in childhood and adolescence can aid in the establishment of lifelong healthy eating patterns and can offer some important nutritional advantages. Vegetarian children and adolescents have lower intakes of cholesterol, saturated fat, and total fat and higher intakes of fruits, vegetables, and fiber than nonvegetarians (2,116-118). Vegetarian children have also been reported to be leaner and to have lower serum cholesterol levels (119-121).

\section{Infants}

When vegetarian infants receive adequate amounts of breast milk or commercial infant formula and their diets contain good sources of energy and nutrients such as iron, vitamin B-12, and vitamin D, growth throughout infancy is normal. Extremely restrictive diets such as fruitarian and raw foods diets have been associated with impaired growth and therefore cannot be recommended for infants and children (29).

Many vegetarian women choose to breastfeed their infants (122), and this practice should be encouraged and supported. The breast milk of vegetarian women is similar in composition to that of nonvegetarians and is nutritionally adequate. Commercial infant formulas should be used if infants are not breastfed or are weaned before 1 year of age. Soy formula is the only option for vegan infants who are not being breastfed.

Soymilk, rice milk, homemade formulas, cow's milk, and goat's milk should not be used to replace breast milk or commercial infant formula during the first year because these foods do not contain the proper ratio of macronutrients nor do they have appropriate micronutrient levels for the young infant.

Guidelines for the introduction of solid foods are the same for vegetarian and nonvegetarian infants (115). When it is time for protein-rich foods to be introduced, vegetarian infants can have mashed or pureed tofu, legumes (pureed and strained if necessary), soy or dairy yogurt, cooked egg yolks, and cottage cheese. Later, foods such as cubes of tofu, cheese or soy cheese, and bite-size pieces of soy burger can be started. Commercial, full-fat, fortified soymilk, or cow's milk can be used as a primary beverage starting at age 1 year or older for a child who is growing normally and is eating a variety of foods (115). Foods that are rich in energy and nutrients such as legume spreads, tofu, and mashed avocado should be used when the infant is being weaned. Dietary fat should not be restricted in children younger than 2 years.

Breastfed infants whose mothers do not consume dairy products, foods fortified with vitamin B-12, or B-12 supplements regularly will need vitamin B-12 supplements (115). Guidelines for the use of iron and vitamin D supplements in vegetarian infants do not differ from guidelines for nonvegetarian infants. Zinc supplements are not routinely recommended for vegetarian infants because zinc deficiency is rarely seen (123). Zinc intake should be individually assessed and zinc supplements or zinc-fortified foods used during the time when complementary foods are being introduced if the diet is low in zinc or mainly consists of foods with low zinc bioavailability $(124,125)$.

\section{Children}

Lacto-ovo-vegetarian children exhibit growth similar to that of their nonvegetarian peers $(114,119,126)$. Little information about the growth of nonmacrobiotic vegan children is available, although findings suggest that children tend to be slightly smaller but within the normal ranges of the standards for weight and height $(114,122)$. Poor growth in children has been seen primarily in those on very restricted diets (127).
Frequent meals and snacks and the use of some refined foods (such as fortified breakfast cereals, breads, and pasta) and foods higher in unsaturated fat can help vegetarian children meet energy and nutrient needs. Average protein intake of vegetarian children (lacto-ovo, vegan, and macrobiotic) generally meets or exceeds recommendations, although vegetarian children may consume less protein than nonvegetarian children $(116,128)$. Vegan children may have protein needs that are slightly higher than those of nonvegan children because of differences in protein digestibility and amino acid composition of plant food proteins $(36,129)$, but these protein needs are generally met when diets contain adequate energy and a variety of plant foods (35). Good sources of calcium, iron, and zinc should be emphasized for vegetarian children along with dietary practices that enhance absorption of zinc and iron from plant foods. A reliable source of vitamin B-12 is important for vegan children. If there is concern about vitamin $\mathrm{D}$ synthesis owing to limited sunlight exposure, skin tone, season, or sunscreen use, vitamin D supplements or fortified foods should be used. The Table provides information about food sources of nutrients. Food guides for vegetarian children under 4 years of age $(36,130)$ and for older children $(72,73)$ have been published elsewhere.

\section{Adolescents}

There are limited data available on the growth of vegetarian adolescents, although studies suggest there is little difference between vegetarians and nonvegetarians (131). In the West, vegetarian girls tend to reach menarche at a slightly later age than nonvegetarians $(132,133)$, although not all research supports this finding $(134,135)$. If slightly later menarche does occur, it may offer health advantages, including lower risk of developing breast cancer and obesity $(136,137)$. Vegetarian diets appear to offer some nutritional advantages for adolescents. Vegetarian adolescents are reported to consume more fiber, iron, folate, vitamin $\mathrm{A}$, and vitamin $\mathrm{C}$ than nonvegetarians $(2,60)$. Vegetarian adolescents also consume more fruits and vegetables and fewer sweets, fast foods, and salty snacks compared with nonvegetarian adolescents $(2,118)$. Key nutrients for adolescent vegetarians include calcium, vitamin D, iron, zinc, and vitamin B-12.

Vegetarian diets are somewhat more common among adolescents with eating disorders than in the general adolescent population; therefore, dietetics professionals should be aware of young clients who greatly limit food choices and who exhibit symptoms of eating disorders $(138,139)$. However, recent data suggest that adopting a vegetarian diet does not lead to eating disorders, rather that vegetarian diets may be selected to camouflage an existing eating disorder $(27,140,141)$. With guidance in meal planning, vegetarian diets are appropriate and healthful choices for adolescents.

\section{Pregnant and Lactating Women}

Lacto-ovo-vegetarian and vegan diets can meet the nutrient and energy needs of pregnant women. Infants of vegetarian mothers generally have birth weights that are similar to those of infants born to nonvegetarians and to birth weight norms $(122,142,143)$. Diets of pregnant and lactating vegans should contain reliable sources of vitamin B-12 daily. If there is concern about vitamin D synthesis because of limited sunlight exposure, skin tone, season, or sunscreen use, pregnant and lactating women should use vitamin D supplements or fortified foods. Iron supplements may be needed to prevent or treat 
iron-deficiency anemia, which is commonly seen during pregnancy. Women capable of becoming pregnant and women in the periconceptional period are advised to consume $400 \mu \mathrm{g}$ of folate daily from supplements, fortified foods, or both in addition to consuming food folate from a varied diet (92).

Infants of vegetarian mothers have been reported to have lower cord and plasma DHA than do infants of nonvegetarians, although the functional significance of this is not known $(104,143)$. Breast milk DHA levels in vegan and lacto-ovo-vegetarian women appear to be lower than levels in nonvegetarians (144). Because DHA seems to play a role in the development of the brain and the eye and because a dietary supply of DHA may be important for the fetus and newborn, pregnant and lactating vegans and vegetarians (unless eggs are eaten regularly) should include sources of the DHA precursor linolenic acid in their diet (ground flaxseed, flaxseed oil, canola oil, soybean oil) or use a vegetarian DHA supplement (from microalgae). Foods containing linoleic acid (corn, safflower, and sunflower oil) and trans-fatty acids (stick margarine, foods with hydrogenated fats) should be limited because these fatty acids can inhibit DHA production from linolenic acid (145).

\section{Older Adults}

Studies indicate that most older vegetarians have dietary intakes that are similar to nonvegetarians $(146,147)$. With aging, energy needs decrease, but recommendations for several nutrients, including calcium, vitamin D, vitamin B6, and possibly protein, are higher. Sunlight exposure is often limited, and vitamin D synthesis is decreased in older adults so that dietary or supplemental sources of vitamin D are especially important.

Older adults may have difficulty with vitamin B-12 absorption from food so vitamin B-12-fortified foods or supplements should be used because the vitamin B-12 in fortified foods and supplements is usually well absorbed (92). Protein requirements for older adults are controversial. The current DRIs do not recommend additional protein for older adults (35). A metaanalysis of nitrogen balance studies concluded that there is not enough evidence to recommend different protein intakes for older adults but pointed out that the data are limited and contradictory (34). Others have concluded that protein requirements of older adults may be around 1 to $1.25 \mathrm{~g} / \mathrm{kg}$ body weight $(148,149)$. Older adults can easily meet protein needs on a vegetarian diet if a variety of protein-rich plant foods, including legumes and soy products, are eaten daily.

Vegetarian diets, which are high in fiber, may be beneficial for older adults with constipation. Older vegetarians may benefit from nutritional counseling on foods that are easy to chew, require minimal preparation, or are appropriate for therapeutic diets.

Athletes
Vegetarian diets can also meet the needs of competitive ath-
letes. Nutrition recommendations for vegetarian athletes
should be formulated with consideration of the effects of both
vegetarianism and exercise. The position of the American Die-
tetic Association and Dietitians of Canada on nutrition and ath-
letic performance (39) provides appropriate dietary guidance
for athletes, although some modification may be needed to
address vegetarians' needs. Protein recommendations for en-
durance athletes are 1.2 to 1.4 g/kg body weight, whereas re-
sistance and strength-trained athletes may need as much as 1.6
to 1.7 g/kg body weight (39). Not all groups support an in-
creased protein need for athletes (35). Vegetarian diets that
meet energy needs and contain a variety of plant-based protein foods, such as soy products, other legumes, grains, nuts, and seeds, can provide adequate protein without the use of special foods or supplements (150). For adolescent athletes, special attention should be given to meeting energy, protein, calcium, and iron needs. Amenorrhea may be more common among vegetarian than nonvegetarian athletes, although not all research supports this finding $(151,152)$. Female vegetarian athletes may benefit from diets that include adequate energy, higher levels of fat, and generous amounts of calcium and iron.

\section{VEGETARIAN DIETS AND CHRONIC DISEASE}

\section{Obesity}

Among Seventh-day Adventists (SDA), 40\% of whom follow a meatless diet, vegetarian eating patterns have been associated with lower body mass index (BMI). In the Adventist Health Study, which compared vegetarians and nonvegetarians within the Adventist population, BMI increased as the frequency of meat consumption increased in both men and women (4). In the Oxford Vegetarian Study, BMI values were higher in nonvegetarians compared with vegetarians in all age groups and for both men and women (112).

In a study of 4,000 men and women in England comparing the relationship between meat consumption and obesity among meat eaters, fish eaters, lacto-ovo-vegetarians, and vegans, mean BMI was highest in the meat eaters and lowest in the vegans (153). BMI was lowest in those lacto-ovo-vegetarians and vegans who had adhered to their diet for 5 years or longer.

Factors that may help to explain the lower BMI among vegetarians include differences in macronutrient content (lower protein, fat, and animal fat intake), higher fiber consumption, decreased alcohol intake, and greater consumption of vegetables.

\section{Cardiovascular Disease}

An analysis of five prospective studies involving more than 76,000 subjects showed that death from ischemic heart disease was $31 \%$ lower among vegetarian men compared with nonvegetarian men and 20\% lower among vegetarian women compared with nonvegetarian women (154). Death rates were also lower for vegetarian men and women compared with semivegetarians, those who ate fish only or ate meat less than once per week. Among SDA, vegetarian men had a 37\% reduction in risk of developing ischemic heart disease compared with nonvegetarian men (4). In the only study to include vegan subjects, risk for developing heart disease was even lower among SDA vegan men than in the SDA lacto-ovo-vegetarians (155).

The lower rates of heart disease among vegetarians are explained in part by their lower blood cholesterol levels. A review of 9 studies found that, in comparison to nonvegetarians, lactoovo-vegetarians and vegans had mean blood cholesterol levels that were $14 \%$ and $35 \%$ lower, respectively (156). Although the lower average BMI of vegetarians may help to explain this, Sacks and colleagues found that, even when vegetarian subjects were heavier than nonvegetarian subjects, the vegetarians had markedly lower plasma lipoprotein values (157), and Thorogood and colleagues found that differences in plasma lipids in vegetarians, vegans, and meat eaters persisted, even following adjustment for BMI (158). Some, but not all, studies have shown lower high-density lipoprotein (HDL) levels in vegetarian subjects (29). Lower HDL levels may be due to the type or amount of dietary fat or to lower alcohol intake. This may help to explain the smaller differences in heart disease rates between vegetarian and nonvegetarian women because HDL 
may be a more important risk factor than LDL levels for women (159). Average triglyceride levels tend to be similar in vegetarians and nonvegetarians.

A number of factors in vegetarian diets may affect cholesterol levels. Although studies show that most vegetarians do not typically consume low-fat diets, saturated fat intake is considerably lower among vegetarians than nonvegetarians, and vegans have a lower ratio of saturated to unsaturated fat in their diets (29). Vegetarians also consume less cholesterol than nonvegetarians, although the range of intake varies considerably across studies. Vegan diets are free of cholesterol.

Vegetarians consume between 50\% and 100\% more fiber than nonvegetarians, and vegans have higher intakes than lacto-ovo-vegetarians (29). Soluble fiber may lower risk for cardiovascular disease by reducing blood cholesterol levels (160). Limited research suggests that animal protein is directly associated with higher serum cholesterol levels even when other dietary factors are controlled (161). Lacto-ovo-vegetarians consume less animal protein than nonvegetarians, and vegans consume no animal protein. Research shows that consumption of at least $25 \mathrm{~g}$ per day of soy protein, either in place of animal protein or in addition to the usual diet, reduces cholesterol levels in people with hypercholesterolemia (162). Soy protein may also raise HDL levels (162). Vegetarians are likely to consume more soy protein than the general population.

Other factors in vegetarian diets may impact cardiovascular disease risk independent of effects on cholesterol levels. Vegetarians have higher intakes of the vitamin antioxidants vitamins $\mathrm{C}$ and $\mathrm{E}$, which may reduce oxidation of LDL cholesterol. Isoflavones, which are phytoestrogens found in soy foods, may also have antioxidant properties (163) as well as enhancing endothelial function and arterial compliance (164). Although there is limited information available about intake of specific phytochemicals among population groups, vegetarians appear to consume more phytochemicals than nonvegetarians because a greater percentage of their energy comes from plant foods. Some phytochemicals may affect plaque formation through effects on signal transduction and cell proliferation (165) and may exert antiinflammatory effects (166). Research from Taiwan found that vegetarians had significantly better vasodilation responses, which correlated directly with years on a vegetarian diet, suggesting a direct beneficial effect of vegetarian diet on vascular endothelial function (167).

Not all aspects of vegetarian diets are associated with reduced risk for heart disease. Some $(89,103,168-171)$ but not all $(62,172)$ studies have found higher serum homocysteine levels in vegetarians compared to nonvegetarians. Homocysteine is believed to be an independent risk factor for heart disease. Inadequate intake of vitamin B-12 may be the explanation. Vitamin B-12 injections lowered homocysteine levels in vegetarians, many of whom had low B-12 levels and high serum homocysteine (173). In addition, low intakes of n-3 fatty acids and a high ratio of n- 6 to n- 3 fatty acids in the diet may raise risk of heart disease among some vegetarians (173).

There are only limited data on the role of vegetarian diets as intervention for heart disease. Vegetarian diets used in these studies have usually been very low in fat. Because these diets have been used along with other lifestyle changes and they have produced weight loss, it has not been possible to ascertain any direct effect of adoption of vegetarian diet on risk factors for heart disease or mortality. Vegetarian diets can be planned to conform to standard recommendations for the treatment of hypercholesterolemia.

\section{Hypertension}

Many studies show that vegetarians have both lower systolic and diastolic pressures with differences between vegetarians and nonvegetarians generally falling between 5 and $10 \mathrm{~mm} \mathrm{Hg}$ (29). In the Hypertension Detection and Follow-Up Program, blood pressure reduction of just $4 \mathrm{~mm} \mathrm{Hg}$ caused marked reduction in mortality from all causes (174).

In addition to having lower blood pressures in general, vegetarians have markedly lower rates of hypertension than meat eaters $(175,176)$. In one study, $42 \%$ of nonvegetarians had hypertension (defined as 140/90 mm Hg) compared with only $13 \%$ of vegetarians. Even semivegetarians are 50\% more likely to have hypertension than vegetarians (4). Even when body weights were similar between subjects, vegetarians had lower blood pressures. Placing nonvegetarian subjects on a vegetarian diet led to reduced blood pressure in normotensive (177) and hypertensive subjects (178).

A number of studies have controlled for various factors that might help to explain the lower blood pressures of vegetarians and the hypotensive effects of changing to a vegetarian diet. The lower blood pressures do not appear to be due to lower BMI (175), exercise habits (179), absence of meat (180), milk protein (181), fat content of diet (182), fiber (183) or differences in potassium, magnesium, or calcium intakes (184). Because sodium intake of vegetarians is comparable or only modestly lower than that of nonvegetarians, sodium does not explain the differences either. Suggested explanations include a difference in blood glucose-insulin response because of a lower glycemic index of vegetarian diets (185) or a collective effect of beneficial compounds from plant foods (186).

\section{Diabetes}

Vegetarian diets can meet guidelines for the treatment of diabetes (187), and some research suggests that diets that are more plant-based reduce risk for type 2 diabetes. Rates of selfreported diabetes among Seventh-day Adventists (SDA) were less than half those of the general population, and, among SDA, vegetarians had lower rates of diabetes than nonvegetarians (188). In the Adventist Health Study, age-adjusted risk for developing diabetes for vegetarian, semivegetarian, and nonvegetarian men was $1.00,1.35$, and 1.97 , respectively, and, for women, it was $1.00,1.08$, and 1.93 (4). Among the possible explanations for a protective effect of vegetarian diet are the lower BMI of vegetarians and higher fiber intake, both of which improve insulin sensitivity. However, among men in the Adventist Health Study, risk for diabetes was still 80\% higher in nonvegetarian men after adjustment for weight. In men, meat consumption was directly associated with increased risk of diabetes. Among women, risk increased only when meat consumption exceeded five servings per week (188).

\section{Cancer}

Vegetarians have an overall lower cancer rate compared with the general population, but it is not clear to what extent this is due to diet. When nondietary cancer risk factors are controlled for, differences in overall cancer rates between vegetarians and nonvegetarians are greatly reduced, although marked differences remain in rates of certain cancers. An analysis from the Adventist Health Study that controlled for age, sex, and smoking found no differences between vegetarians and nonvegetarians for lung, breast, uterine, or stomach cancer but did find that nonvegetarians had a 54\% increased risk for prostate cancer and an 88\% increased risk for colorectal cancer (4). Other 
research has shown lower rates of colon cell proliferation in vegetarians compared with nonvegetarians (189) and lower levels of serum insulin-like growth factor-I, thought to be involved in the etiology of several cancers in vegans compared with both nonvegetarians and lacto-ovo-vegetarians (190). Both red and white meat have been independently linked to increased risk for colon cancer (4). Observational studies have found an association between high intake of dairy foods and calcium with increased risk for prostate cancer (191-193), although not all studies support this finding (194). A pooled analysis of 8 observational studies found no link between meat or dairy consumption and breast cancer (195).

Research suggests that a number of factors in vegetarian diets may impact cancer risk. Vegetarian diets come closer to matching the dietary guidelines issued by the National Cancer Institute than do nonvegetarian diets, particularly in regard to fat and fiber intakes (196). Although data on fruit and vegetable intake of vegetarians are limited, a recent study found that intake was considerably higher among vegans compared with nonvegetarians (62). High lifetime exposure to estrogen has been linked to increased breast cancer risk. Some research shows that vegetarians have lower serum and urinary estrogen levels (197). There is also some evidence that vegetarian girls begin menstruation at a later age, which may reduce cancer risk because of lower lifetime estrogen exposure $(132,133)$. High fiber intake is believed to protect against colon cancer, although not all research supports this $(198,199)$. The environment of the colon of vegetarians is strikingly different from that of nonvegetarians. Vegetarians have a lower concentration of potentially carcinogenic bile acids (200) and fewer intestinal bacteria that convert the primary bile acids into carcinogenic secondary bile acids (201). More frequent elimination and the levels of certain enzymes in the colon enhance elimination of potential colon carcinogens $(200,202)$. Most research shows that vegetarians have lower levels of fecal mutagens (203).

Vegetarians do not consume heme iron, which has been shown to lead to the formation of highly cytotoxic factors in the colon increasing colon cancer risk (204). Finally, vegetarians most likely have higher intakes of phytochemicals, many of which have anticancer activity. Isoflavones in soy foods have been shown to have anticancer effects, particularly in regard to breast and prostate cancer, although this is not supported by all research $(205,206)$.

\section{Osteoporosis}

Osteoporosis is a complex disease affected by a variety of lifestyle, dietary, and genetic factors. Although some data indicate that osteoporosis is less common in developing countries with a mostly plant-based diet, these studies have relied on hip fracture data, which has been found to be unreliable for comparing bone health across cultures. There is little evidence to suggest that bone mineral density differs between western nonvegetarians and lacto-ovo-vegetarians.

A number of studies have shown that high protein intake, from animal foods in particular, causes increased excretion of calcium and raises calcium needs (207-209). The effect is believed to be due to the increased acid load from metabolism of sulfur-containing amino acids (SAA). However, grains are also high in these amino acids, and some research shows that SAA intake was similar between nonvegetarians and vegetarians (210). Despite this, there is some evidence that postmenopausal women with diets high in animal protein and low in plant protein had a high rate of bone loss and a greatly increased risk of hip fracture (211). Although excessive protein intake may compromise bone health, there is evidence that low protein intakes could raise risk for poorer bone health (212). Although there are very little reliable data on bone health of vegans, some studies suggest that bone density is lower among vegans compared with nonvegetarians (213-215). Vegan women, like other women, may have low calcium intakes despite the availability of nondairy sources of well-absorbed calcium. Some vegan women may also have protein intakes that are marginal, and vitamin $\mathrm{D}$ status has shown to be compromised in some vegans (216-218). The lower serum estrogen levels of vegetarians may be a risk factor for osteoporosis. In contrast, short-term clinical studies suggest that soy protein rich in isoflavones decreases spinal bone loss in postmenopausal women (219). Higher intake of potassium and vitamin $\mathrm{K}$ among vegetarians may also help to protect bone health. However, the data suggest that a vegetarian diet does not necessarily protect against osteoporosis despite lower animal protein content.

\section{Renal Disease}

High intake of dietary protein may worsen existing kidney disease or increase risk for those who are susceptible to this disease because protein intake is associated with a higher glomerular filtration rate (GFR) (220). The GFR of healthy vegetarians is lower than that of nonvegetarians and even lower in vegans (221). The type of protein consumed may also have an effect, with plant foods having a more beneficial effect on GFR than animal protein $(222,223)$. GFR was $16 \%$ higher in healthy subjects after eating a meal containing animal protein compared with a meal with soy protein (222). Because the pathology of renal disease is similar to that of atherosclerosis, the lower serum cholesterol levels and reduced cholesterol oxidation resulting from a vegetarian diet may be beneficial for those with kidney disease.

\section{Dementia}

Although rates of dementia differ markedly throughout the world, differences in diagnostic criteria make cross-cultural comparisons difficult. In the United States, among SDA, those who ate meat were more than twice as likely to develop dementia (224). Those who had eaten meat for many years were more than three times as likely to develop signs of dementia. Diets high in antioxidants have been found to protect cognitive function (225-227). The lower blood pressure of vegetarians may also be protective. There is also some evidence that lower blood cholesterol protects against dementia (228). Higher homocysteine levels are linked to increased risk of dementia, and this may present one risk factor for vegetarians who do not get adequate vitamin B-12 (229-232). Although one observational study found an increased rate of dementia among Japanese American men who ate tofu regularly (233), the study had a number of methodological limitations, and other research has not supported these findings (234).

\section{Other Health Effects of Vegetarian Diets Diverticular disease}

Gear and colleagues found that both male and female vegetarians aged 45 to 59 years were $50 \%$ as likely to have diverticulitis compared with nonvegetarians (235). Although fiber is believed to be the most important reason for this difference, other factors may have an effect as well. High-fat diets, independent of fiber intake, have been associated with increased risk of 
diverticulitis (236). Meat intake may also increase risk (236). Older research suggests that meat consumption may promote growth of bacteria that produce a toxic metabolite that weakens the wall of the colon (237).

\section{Gallstones}

In a study of 800 women aged 40 to 69 years, nonvegetarians were more than twice as likely as vegetarians to suffer from gallstones (238). The relationship held even after controlling for the three known risk factors for gallstones: obesity, gender, and aging.

\section{Rheumatoid arthritis}

Rheumatoid arthritis (RA), believed to be an autoimmune disease, involves inflammation of the joints. Several studies from one group of researchers in Finland suggest that fasting, followed by vegan diet, may be useful in treatment of RA $(239,240)$.

Although data are very limited and more follow-up is needed before conclusions can be drawn, some studies suggest that a mostly raw foods vegan diet reduces symptoms of fibromyalgia (241) and that a vegetarian diet may reduce symptoms of topical dermatitis (242).

\section{PROGRAMS AND AUDIENCES IMPACTED}

\section{Special Supplemental Nutrition Program for Women, Infants, and Children}

In the United States, the Special Supplemental Nutrition Program for Women, Infants, and Children (WIC) is a federal grant program that serves pregnant, postpartum, and breastfeeding women and infants and children up to 5 years of age who are documented as being at nutritional risk and with family income below state standards. This program provides checks or coupons to purchase some foods suitable for vegetarians, including infant formula, iron-fortified infant cereal, vitamin C-rich fruit or vegetable juice, carrots, cow's milk, cheese, eggs, iron-fortified ready-to-eat cereal, dried beans or peas, and peanut butter. Individual state agencies are allowed to submit a plan to USDA's Food and Nutrition Service for substitution of foods to allow for different cultural eating patterns, provided the proposed substitute food is nutritionally equivalent or superior to the food it replaces, is widely available, and does not cost more than the food it is to replace (243). This provision could possibly allow more foods suitable for vegans to be purchased.

Canada Prenatal Nutrition Program (CPNP), federally funded by Health Canada, and perinatal community programs provide vouchers, coupons, or groceries to those who meet the income and nutritional risk criteria for the program. Vouchers can be used for some foods acceptable to vegetarians, including milk, juice, cheese, eggs, fortified soymilk, and other foods (244).

\section{Child Nutrition Programs}

In the United States, the National School Lunch Program (NSLP) allows nonmeat protein products, including certain soy products, cheese, eggs, cooked dried beans or peas, yogurt, peanut butter, other nut or seed butters, peanuts, tree nuts, and seeds to be used $(245,246)$. USDA information for school foodservice personnel includes several vegetarian and vegan quantity recipes (247). Few public schools regularly feature vegetarian menu items. School lunches are not adequate for vegans even when some vegan options are available because soymilk can only be served as a part of school lunch in cases of documented lactose intolerance.
In Canada, school lunch, breakfast, and snack programs; food selection standards; and provision for vegetarian meals vary from one region to another. Nationally, the Canadian Living Foundation's Breakfast for Learning program is developing Best Practice Program Standards for breakfast, snack, and lunch programs. Vegetarian meals based on Canada's Food Guide to Healthy Eating fit within this framework (248).

\section{Feeding Programs for the Elderly}

The federal Elderly Nutrition Program (ENP) distributes funds to states, territories, and tribal organizations for a national network of programs that provide congregate and home-delivered meals (often known as Meals on Wheels) for older Americans. Meals served under this program must provide at least onethird of the RDAs (249). Meals are often provided by local Meals on Wheels agencies. A 4-week set of vegetarian menus has been developed for use by the National Meals on Wheels Foundation $(250,251)$.

\section{Corrections Facilities}

Court rulings in the United States and Canada have granted prison inmates the right to have vegetarian meals for religious and medical reasons (and in Canada, by choice, as well) $(252,253)$. Federal institutions and those for many states and provinces provide vegetarian options for meals. The Canadian federal court has ruled that prison inmates who are opposed to eating meat have a constitutional right to be served vegetarian meals. The Freedom of Conscience provisions in the Charter of Rights allow prisoners to demand vegetarian fare for moral reasons, just as other inmates may request special meals on religious or medical grounds (252).

\section{Military/Armed Forces}

The US Army's Combat Feeding Program, which oversees all food regulations, provides a choice of vegetarian menus (254). Canadian Forces Food Services offers one or more vegetarian options at every meal (255). An estimated $10 \%$ to $15 \%$ of $\mathrm{Ca}-$ nadian Forces members choose vegetarian meals for combat rations (individual meal packs) (256).

\section{Other Institutions and Quantity Food Service Organizations}

Other institutions, including colleges, universities, hospitals, restaurants, and publicly funded museums and parks offer varying amounts and types of vegetarian selections. Resources are available for vegetarian quantity food preparation (Figure 1). As interest in vegetarianism grows and because of the nutritional and health benefits of choosing a vegetarian diet, increased provision of vegetarian meals on a daily basis should be encouraged.

\section{ROLE OF DIETETICS PROFESSIONALS}

Vegetarian clients may seek nutrition counseling services for a specific clinical condition or for assistance in planning healthful vegetarian diets. They may sometimes be referred because of problems related to poor diet choices. Dietetics professionals have an important role in supporting clients who express an interest in adopting vegetarian diets or who already eat a vegetarian diet. It is important for dietetics professionals to support any client who chooses this style of eating and to be able to give current accurate information about vegetarian nutrition. Information should be individualized depending on type of vegetarian diet, age of the client, food preparation skills, and ac- 
tivity level. It is important to listen to the client's own description of his or her diet to ascertain which foods can play a role in meal planning. Figure 1 provides a listing of Web resources on vegetarianism. Figure 2 includes meal planning tips.

Qualified dietetics professionals can help vegetarian clients in the following ways:

- provide information about meeting requirements for vitamin B-12, calcium, vitamin D, zinc, iron, and n-3 fatty acids because poorly planned vegetarian diets may sometimes fall short of these nutrients;

- give specific guidelines for planning balanced lacto-ovo-vegetarian or vegan meals for all stages of the life cycle;

- adapt guidelines for planning balanced lacto-ovo-vegetarian or vegan meals for clients with special dietary needs because of allergies or chronic disease or other restrictions;

- be familiar with vegetarian options at local restaurants;

- provide ideas for planning optimal vegetarian meals while traveling;

- instruct clients about the preparation and use of foods that frequently are part of vegetarian diets; the growing selection of products aimed at vegetarians may make it impossible to be

\section{General Vegetarian Nutrition: \\ Food and Nutrition Information Center, USDA http://www.nal.usda.gov/fnic/etext/000058.html \\ http://www.nal.usda.gov/fnic/pubs/bibs/gen/vegetarian.htm}

Loma Linda University Vegetarian Nutrition \& Health Letter http://www.llu.edu/llu/vegetarian/vegnews.htm

Seventh-day Adventist Dietetic Association http://www.sdada.org/facts\&fiction.htm

\section{Vegan Outreach}

http://www.veganoutreach.org/whyvegan/health.html;

http://www.veganoutreach.org/health/stayinghealthy.html

The Vegan Society (vitamin B-12)

www. vegansociety.com/html/info/b12sheet.htm

Vegetarian Nutrition Dietetic Practice Group

http://www.vegetariannutrition.net/

Vegetarian Resource Group

http://www.vrg.org/

The Vegetarian Society of the United Kingdom

http://www.vegsoc.org/health/

VegRD

http://vegrd.vegan.com/

Travel:

Happy Cow's Global Guide to Vegetarian Restaurants www.happycow.net/

VegDining.com

www.vegdining.com/Home.cfm

Vegetarian Resource Group

www.vrg.org/travel/

Quantity Food Preparation:

Vegetarian Resource Group

http://www.vrg.org/fsupdate/

FIG 1. Useful Web sites.
A variety of menu planning approaches can provide adequate nutrition for vegetarians. The Vegetarian Food Guide Pyramid and Vegetarian Food Guide Rainbow $(72,73)$ suggest one approach. In addition, the following guidelines can help vegetarians plan healthful diets:

- Choose a variety of foods including whole grains, vegetables, fruits, legumes, nuts, seeds, and if desired, dairy products, and eggs.

- Choose whole, unrefined foods often and minimize the intake of highly sweetened, fatty and heavily refined foods.

- Choose a variety of fruits and vegetables.

- If animal foods such as dairy products and eggs are used, choose lower-fat dairy products and use both eggs and dairy products in moderation.

- Use a regular source of vitamin B-12 and, if sunlight exposure is limited, of vitamin D.

FIG 2. Meal planning.

knowledgeable about all such products. However, practitioners working with vegetarian clients should have a basic knowledge of preparation, use, and nutrient content of a variety of grains, beans, soy products, meat analogs and fortified foods.

- be familiar with local sources for purchase of vegetarian foods. In some communities, mail order sources may be necessary.

- work with family members, particularly the parents of vegetarian children, to help provide the best possible environment for meeting nutrient needs on a vegetarian diet; and,

- if a practitioner is unfamiliar with vegetarian nutrition, he/she should assist the individual in finding someone who is qualified to advise the client or should direct the client to reliable resources.

\section{CONCLUSIONS}

Appropriately planned vegetarian diets have been shown to be healthful, nutritionally adequate, and beneficial in the prevention and treatment of certain diseases. Vegetarian diets are appropriate for all stages of the life cycle. There are many reasons for the rising interest in vegetarianism. The number of vegetarians in the United States and Canada is expected to increase over the next decade. Dietetics professionals can assist vegetarian clients by providing current, accurate information about vegetarian nutrition, foods, and resources.

\section{References}

1. Barr SI, Chapman GE. Perceptions and practices of self-defined current vegetarian, former vegetarian, and nonvegetarian women. J Am Diet Assoc. 2002;102:354-360.

2. Perry CL, McGuire MT, Neumark-Sztainer D, Story M. Adolescent vegetarians. How well do their dietary patterns meet the Healthy People 2010 objectives? Arch Pediatr Adolesc Med. 2002;156:431-437.

3. Sabate J, Ratzin-Turner RA, Brown JE. Vegetarian diets: descriptions and trends. In: Sabate J, ed. Vegetarian Nutrition. Boca Raton, FL: CRC Press; 2001:3-17.

4. Fraser GE. Associations between diet and cancer, ischemic heart disease, and all-cause mortality in non-Hispanic white California Seventh-day Adventists. Am J Clin Nutr. 1999;70:532S-538S.

5. White RF, Seymour J, Frank E. Vegetarianism among US women physicians. J Am Diet Assoc. 1999;99:595-598.

6. Lea E, Worsley A. The cognitive contexts of beliefs about the healthiness of meat. Public Health Nutr. 2002;5:37-45.

7. The Vegetarian Resource Group. How many vegetarians are there? Available at: http://www.vrg.org/nutshell/poll2000.htm. Accessed February 10, 2003. 8. The Vegetarian Resource Group. How many teens are vegetarian? How many kids don't eat meat? Available at: http://www.vrg.org/journal/vj2001jan/ 2001janteen.htm. Accessed February 10, 2003.

9. National Institute of Nutrition. Tracking Nutrition Trends IV: An Update on 
Canadians' Nutrition-Related Attitudes, Knowledge and Actions, 2001. Available at: www.nin.ca/public_html/EN/consumer_trends.html. Accessed February 10, 2003.

10. Raj S, Ganganna P, Bowering J. Dietary habits of Asian Indians in relation to length of residence in the United States. J Am Diet Assoc. 1999;99:11061108.

11. Ginsberg C, Ostrowski A. The market for vegetarian foods. Vegetarian J. 2002;4:25-29.

12. The Vegetarian Resource Group. How many people order vegetarian foods when eating out? Available at: http://www.vrg.org/journal/vj99sep/ 999scientific.htm. Accessed February 10, 2003.

13. National Restaurant Association. Tableservice Restaurant Trends, 2001. Washington, DC: 2001.

14. Crosby M. College and university foodservice operations get high marks from students; 1999. Available at: http://www.restaurant.org/rusa/magArticle. cfm?ArticlelD=327. Accessed February 10, 2003.

15. Sabate J, Duk A, Lee CL. Publication trends of vegetarian nutrition articles in biomedical literature; 1966-1995. Am J Clin Nutr. 1999;70(suppl):601S-607S. 16. World Cancer Research Fund/AICR. Food, Nutrition, and the Prevention of Cancer: A Global Perspective. Washington, DC: AICR; 1997.

17. Byers T, Nestle M, McTiernan A, Doyle C, Currie-Williams A, Gansler T, Thun M. American Cancer Society 2001 Nutrition and Physical Activity Guidelines Advisory Committee. American Cancer Society guidelines on nutrition and physical activity for cancer prevention: Reducing the risk of cancer with healthy food choices and physical activity. CA Cancer J Clin. 2002;52:92-119. 18. Nutrition Committee of the American Heart Association. AHA Dietary Guidelines Revision 2000: A Statement for Healthcare Professionals From the Nutrition Committee of the American Heart Association. Circulation. 2000; 102:2296-2311.

19. Heart and Stroke Foundation of Canada. Healthy Eating. Available at: http://ww2.heartandstroke.ca/Page.asp?PagelD $=33 \&$ ArticlelD $=551 \&$ Src $=$ living\&From=SubCategory. Accessed February 10, 2003.

20. Deckelbaum RJ, Fisher EA, Winston M, Kumanyika, Lauer RM, Pi-Sunyer FX, St. Jeor, S, Schaefer EJ, Weinstein IB. Summary of a scientific conference on preventive nutrition: Pediatrics to geriatrics. Circulation. 1999;100:450-456.

21. Mintel International Group Limited. The Vegetarian Food Market-US Report. Chicago, IL: Mintel International Group Limited; 2001.

22. AC Nielsen. Market Track for 1997 to 2001. New York, NY: AC Nielsen; 2001.

23. US Department of Agriculture. Dietary Guidelines for Americans, 5th ed. Washington, DC: US Government Printing Office; 2000.

24. Haddad EH. Vegetarian diets and dietary guidelines for chronic disease prevention: How meatless diets conform to current recommendations for healthy eating. In: Sabate J, ed. Vegetarian Nutrition. Boca Raton, FL: CRC Press; 2001:371-409.

25. Dietitians of Canada. Celebrating the pleasure of vegetarian eating. Available at: http://www.dietitians.ca/english/factsheets/e1995_02.html. Accessed February 10, 2003.

26. Health Canada. Nutrition for a Healthy Pregnancy: National Guidelines for the Childbearing Years. Ottawa: Minister of Public Works and Government Services Canada; 1999.

27. Janelle KC, Barr SI. Nutrient intakes and eating behavior scores of vegetarian and nonvegetarian women. J Am Diet Assoc. 1995;95:180-189.

28. Jacob RA, Burri BJ. Oxidative damage and defense. Am J Clin Nutr. 1996;63:985S-990S.

29. Messina MJ, Messina VL. The Dietitian's Guide to Vegetarian Diets: Issues and Applications. Gaithersburg, MD: Aspen Publishers; 1996.

30. Rainey CJ, Nyquist LA, Christensen RE, Strong PL, Culver BD, Coughlin JR. Daily boron intake from the American diet. J Am Diet Assoc. 1999;99: 335-340.

31. Larsson CL, Johansson GK. Dietary intake and nutritional status of young vegans and omnivores in Sweden. Am J Clin Nutr. 2002;76:100-106.

32. Young VR, Pellett PL. Plant proteins in relation to human protein and amino acid nutrition. Am J Clin Nutr. 1994;59:1203S-1212S.

33. Joint FAO/WHO Expert Consultation. Protein Quality Evaluation. FAO Food and Nutrition Paper 51. Rome; 1991.

34. Rand WM, Pellett PL, Young VR. Meta-analysis of nitrogen balance studies for estimating protein requirements in healthy adults. Am J Clin Nutr. 2003;77:109-127.

35. Food and Nutrition Board, Institute of Medicine. Dietary Reference Intakes for Energy, Carbohydrate, Fiber, Fat, Fatty Acids, Cholesterol, Protein, and Amino Acids. Washington, DC: National Academy Press; 2002.

36. Messina V, Mangels AR. Considerations in planning vegan diets: Children. J Am Diet Assoc. 2001;101:661-669.

37. Young VR, Fajardo L, Murray E, Rand WM, Scrimshaw NS. Protein requirements of man: Comparative nitrogen balance response within the submaintenance-to-maintenance range of intakes of wheat and beef proteins. J Nutr. 1975;105:534-542.
38. Nieman DC. Physical fitness and vegetarian diets: Is there a relation? Am J Clin Nutr. 1999;70:570S-575S.

39. American Dietetic Association, Dietitians of Canada, the American College of Sports Medicine. Nutrition and athletic performance-Position of the American Dietetic Association, Dietitians of Canada, and the American College of Sports Medicine. J Am Diet Assoc. 2000;100:1543-1556.

40. Hurrell RF, Reddy M, Cook JD. Inhibition of non-haem iron absorption in man by polyphenolic-containing beverages. Br J Nutr. 1999;81:289-295.

41. Gillooly M, Bothwell TH, Torrance JD, MacPhail AP, Derman DP, Bezwoda WR, Mills W, Charlton RW. The effects of organic acids, phytates, and polyphenols on the absorption of iron from vegetables. Br J Nutr. 1983;49:331-342. 42. Hallberg L, Hulthen L. Prediction of dietary iron absorption: An algorithm for calculating absorption and bioavailability of dietary iron. Am J Clin Nutr. 2000;71:1147-1160.

43. Sandstrom B. Micronutrient interactions: Effects on absorption and bioavailability. Br J Nutr. 2001;85(suppl 2):S181-S185.

44. Food and Nutrition Board, Institute of Medicine. Dietary Reference Intakes for Vitamin A, Vitamin K, Arsenic, Boron, Chromium, Copper, lodine, Iron, Manganese, Molybdenum, Nickel, Silicon, Vanadium, and Zinc. Washington, DC: National Academy Press; 2001.

45. Brune M, Rossander-Hulten L, Hallberg L, Gleerup A, Sandberg AS. Iron absorption from bread in humans: Inhibiting effects of cereal fiber, phytate and inositol phosphates with different numbers of phosphate groups. J Nutr. 1992;122:442-449.

46. Coudray C, Bellanger J, Castiglia-Delavaud C, Remesy C, Vermorel M, Rayssignuier Y. Effect of soluble or partly soluble dietary fibres supplementation on absorption and balance of calcium, magnesium, iron and zinc in healthy young men. Eur J Clin Nutr. 1997;51:375-380.

47. Backstrand JR, Allen LH, Black AK, De Mata M, Pelto GH. Diet and iron status of nonpregnant women in rural Central Mexico. Am J Clin Nutr. 2002; 76:156-164.

48. Fleming DJ, Jacques PF, Dallal GE, Tucker KL, Wilson PW, Wood RJ. Dietary determinants of iron stores in a free-living elderly population: The Framingham Heart Study. Am J Clin Nutr. 1998;67:722-733.

49. Frolich W. Chelating properties of dietary fiber and phytate: The role for mineral availability: In: Furda I, Brine CJ, eds. New Developments in Dietary Fiber. New York, NY: Plenum Press; 1990.

50. Harland BF, Morris E R. Phytate a good or bad food component. Nutr Res. 1995;15:733-754.

51. Sandberg AS, Brune M, Carlsson NG, Hallberg L, Skoglund E, RossanderHulthen L. Inositol phosphates with different numbers of phosphate groups influence iron absorption in humans. Am J Clin Nutr. 1999;70:240-246.

52. Manary MJ, Krebs NF, Gibson RS, Broadhead RL, Hambidge KM. Community-based dietary phytate reduction and its effect on iron status in Malawian children. Ann Trop Paediatr. 2002;22:133-136.

53. Bhatia A, Khetarpaul N. Development, acceptability and nutritional evaluation of "Doli Ki Roti"- -an indigenously fermented bread. Nutr Health. 2001; 15:113-120.

54. El-Guindi M, Lynch SR, Cook JD. Iron absorption from fortified flat breads. Br J Nutr. 1988;59:205-213.

55. Macfarlane BJ, van der Riet WB, Bothwell TH, Baynes RD, Siegenberg D, Schmidt U, Tol A, Taylor JRN, Mayet F. Effect of traditional Oriental soy products on iron absorption. Am J Clin Nutr. 1990;51:873-880.

56. Hunt JR, Roughead ZK. Nonheme-iron absorption, fecal ferritin excretion, and blood indexes of iron status in women consuming controlled lactoovovegetarian diets for 8 wk. Am J Clin Nutr. 1999;69:944-952.

57. Hunt JR, Roughead ZK. Adaptation of iron absorption in men consuming diets with high or low iron bioavailability. Am J Clin Nutr. 2000;71:94-102.

58. Ball MJ, Bartlett MA. Dietary intake and iron status of Australian vegetarian women. Am J Clin Nutr. 1999;70:353-358.

59. Alexander D, Ball MJ, Mann J. Nutrient intake and haematological status of vegetarians and age-sex matched omnivores. Eur J Clin Nutr. 1994;48:538-546. 60. Donovan UM, Gibson RS. Iron and zinc status of young women aged 14 to 19 years consuming vegetarian and omnivorous diets. J Am Coll Nutr. 1995; 14:463-472.

61. Harman, SK, Parnell, WR The nutritional health of New Zealand vegetarian and non-vegetarian Seventh-day Adventists: Selected vitamin, mineral and lipid levels. N Z Med J. 1998;111:91-94.

62. Haddad EH, Berk LS, Kettering JD, Gubbard RW, Peters WR. Dietary intake and biochemical, hematologic, and immune status of vegans compared with nonvegetarians. Am J Clin Nutr. 1999;70:586S-593S.

63. Hunt JR, Matthys LA, Johnson LK. Zinc absorption, mineral balance, and blood lipids in women consuming controlled lactoovovegetarian and omnivorous diets for 8 weeks. Am J Clin Nutr. 1998;67:421-430.

64. Ball MJ, Ackland ML. Zinc intake and status in Australian vegetarians. Br J Nutr. 2000;83:27-33.

65. Gibson RS. Content and bioavailability of trace elements in vegetarian diets. Am J Clin Nutr. 1994;59:1223S-1232S. 
66. Hunt JR. Moving toward a plant-based diet: Are iron and zinc at risk? Nutr Rev. 2002;60:127-134.

67. Lei S, Mingyan X, Miller LV, Tong L, Krebs NF, Hambidge KM. Zinc absorption and intestinal losses of endogenous zinc in young Chinese women with marginal zinc intakes. Am J Clin Nutr. 1996;63:348-353.

68. Gibson RS, Hotz C. Dietary diversification/modification strategies to enhance micronutrient content and bioavailability of diets in developing countries. Br J Nutr. 2001;85(suppl 2):S159-S166.

69. Heaney R, Dowell M, Rafferty K, Bierman J. Bioavailability of the calcium in fortified soy imitation milk, with some observations on method. Am J Clin Nutr. 2000;71:1166-1169.

70. Weaver C, Plawecki K. Dietary calcium: Adequacy of a vegetarian diet. Am J Clin Nutr. 1994;59:1238S-1241S.

71. Weaver C, Proulx W, Heaney R. Choices for achieving adequate dietary calcium with a vegetarian diet. Am J Clin Nutr. 1999;70:543S-548S.

72. Messina V, Melina V, Mangels AR. A new food guide for North American vegetarians. J Am Diet Assoc. 2003;103:771-775.

73. Messina V, Melina V, Mangels AR. A new food guide for North American vegetarians. Can J Diet Pract Res. 2003;64(2).

74. Slattery ML, Jacobs DR Jr, Hilner JE, Caan BJ, Van Horn L, Bragg C Manolio TA, Kushi LH, Liu KA. Meat consumption and its associations with other diet and health factors in young adults: The CARDIA study. Am J Clin Nutr. 1991;54:930-935.

75. Tesar R, Notelovitz M, Shim E, Dauwell G, Brown J. Axial and peripheral bone density and nutrient intakes of postmenopausal vegetarian and omnivorous women. Am J Clin Nutr. 1992;56:699-704.

76. Remer T. Influence of diet on acid-base balance. Semin Dial. 2000;13: 221-226.

77. Food and Nutrition Board, Institute of Medicine. Dietary Reference Intakes for Calcium, Phosphorus, Magnesium, Vitamin D and Fluoride. Washington, DC: National Academy Press; 1997.

78. Heaney RP, Dowell SD, Bierman J, Hale CA, Bendich A. Absorbability and cost effectiveness in calcium supplementation. J Am Coll Nutr. 2001;20:239246.

79. Holick MF. Vitamin D and bone health. J Nutr. 1996;126:1159S-1164S

80. Lee LT, Drake WM, Kendler DL. Intake of calcium and vitamin D in 3 Canadian long-term care facilities. J Am Diet Assoc. 2002;102:244-247.

81. Moloney FJ, Collins S, Murphy GM. Sunscreens: Safety, efficacy and appropriate use. Am J Clin Dermatol. 2002;3:185-191.

82. Weinstock MA. Do sunscreens increase or decrease melanoma risk: An epidemiologic evaluation. J Investig Dermatol Symp Proc. 1999;4:97-100. 83. Dagnelie PC, Vergote FJ, van Staveren WA, van den Berg H, Dingjan PG, Hautvast JG. High prevalence of rickets in infants on macrobiotic diets. Am J Clin Nutr. 1990;51:202-208.

84. Parsons $T J$, van Dusseldorp $M$, van der Vliet $M$, van de Werken $K$ Schaafsma G, van Staveren WA. Reduced bone mass in Dutch adolescents fed a macrobiotic diet in early life. J Bone Miner Res. 1997;12:1486-1494.

85. Fonseca V, Agnew JE, Nag D, Dandona P. Bone density and cortica thickness in nutritional vitamin D deficiency: Effect of secondary hyperparathyroidism. Ann Clin Biochem. 1988;25:271-274.

86. Trang HM, Cole DE, Rubin LA, Pierratos A, Siu S, Vieth R. Evidence that vitamin D-3 increases serum 25-hydroxyvitamin D more efficiently than does vitamin D-2. Am J Clin Nutr. 1998;68:854-858.

87. US Department of Agriculture, Agricultural Research Service, 2002. USDA Nutrient Database for Standard Reference, Release 15. Nutrient data laboratory home page. Available at: http://www.nal.usda.gov/fnic/foodcomp. Accessed February 10, 2003.

88. Donaldson MS. Metabolic vitamin B12 status on a mostly raw vegan diet with follow-up using tablets, nutritional yeast, or probiotic supplements. Ann Nutr Metab. 2000;44:229-234.

89. Herrmann W, Schorr H, Purschwitz K, Rassoul F, Richter V. Total homocysteine, vitamin B12, and total antioxidant status in vegetarians. Clin Chem. 2001;47:1094-1101.

90. Herrmann W, Geisel J. Vegetarian lifestyle and monitoring of vitamin B-12 status. Clin Chim Acta. 2002;326:47-59.

91. Luhby AL, Cooperman JM, Donnenfeld AM, Herman JM, Teller DN, Week JB. Observations on transfer of vitamin $B_{12}$ from mother to fetus and newborn. Am J Dis Child. 1958;96:532-533

92. Food and Nutrition Board, Institute of Medicine. Dietary Reference Intakes for Thiamin, Riboflavin, Niacin, Vitamin $B_{6}$, Folate, Vitamin $B_{12}$, Pantothenic Acid, Biotin, and Choline. Washington, DC: National Academy Press; 1998. 93. Barr SI, Broughton TM. Relative weight, weight loss efforts and nutrient intakes among health-conscious vegetarian, past vegetarian and nonvegetarian women ages 18 to 50. J Am Coll Nutr. 2000;19:781-788.

94. Herbert V. Staging vitamin $B_{12}$ (cobalamin) status in vegetarians. Am J Clin Nutr. 1994;59:1213S-1222S.

95. Hokin BD, Butler T. Cyanocobalamin (vitamin B-12) status in Seventh-day Adventist ministers in Australia. Am J Clin Nutr. 1999;70:576S-578S.
96. van het Hof $\mathrm{KH}$, Brouwer IA, West CE, Haddeman E, Steegers-Theunissen RP, von Dussledorp M, Weststrate JA, Ekes TK, Hautvast JG. Bioavailability of lutein from vegetables is five times higher than that of beta carotene. Am J Clin Nutr. 1999;70:261-268.

97. Hedren E, Diaz V, Svanberg U. Estimation of carotenoid accessibility from carrots determined by an in vitro digestion method. Eur J Clin Nutr 2002; 56:425-430.

98. Castenmiller JJ, West CE, Linssen JP, van het Hof KH, Voragen AG. The food matrix of spinach is a limiting factor in determining the bioavailability of beta carotene and to a lesser extent of lutein in humans. J Nutr. 1999;129: 349-355.

99. Ribaya-Mercado JD. Influence of dietary fat on beta carotene absorption and bioconversion into vitamin A. Nutr Rev. 2002;60:104-110.

100. Conquer JA, Holub BJ. Supplementation with an algae source of docosahexaenoic acid increases (n-3) fatty acid status and alters selected risk factors for heart disease in vegetarian subjects. J Nutr. 1996;126:3032-3039. 101. Ågren JJ, Tormala ML, Nenonen MT, Hanninen OO. Fatty acid composition of erythrocyte, platelet, and serum lipids in strict vegans. Lipids. 1995; 30:365-369.

102. Krajcovicova-Kudlackova $M$, Simoncic $R$, Babinska $K$, Bederova $A$. Levels of lipid peroxidation and antioxidants in vegetarians. Eur J Epidemiol. 1995;11:207-211.

103. Mezzano D, Munoz X, Marinez C, Cuevas A, Panes O, Aranda E, Guasch V, Strobel P, Munoz B, Rodriguez S, Pereira J, Leighton F. Vegetarians and cardiovascular risk factors: Hemostasis, inflammatory markers and plasma homocysteine. Thromb Haemost. 1999;81:913-917.

104. Reddy S, Sanders TA, Obeid $O$. The influence of maternal vegetarian diet on essential fatty acid status of the newborn. Eur J Clin Nutr. 1994;48:358368 .

105. Joint WHO/FAO Expert Consultation on Diet, Nutrition and the Prevention of Chronic Diseases. Diet, Nutrition and the Prevention of Chronic Diseases. Draft. Geneva, Switzerland. Jan 28 to Feb 1, 2002. Available at: http://www.who.int/hpr/nutrition/26Aprildraftrev1.pdf. Accessed February 10, 2003.

106. Davis B, Kris-Etherton P. Achieving optimal essential fatty acid status in vegetarians: Current knowledge and practical implications. Am J Clin Nutr. In press.

107. Kris-Etherton PM, Taylor DS, Yu-Poth S, Huth P, Moriarty K, Fishell V, Hargrove RL, Zhao G, Etherton TD. Polyunsaturated fatty acids in the food chain in the United States. Am J Clin Nutr. 2000;71:179S-188S.

108. Indu, M and Ghafoorunissa. N-3 fatty acids in Indian diets-comparison of the effects of precursor (alpha-linolenic acid) vs. product (long chain n-3 polyunsaturated fatty acids). Nutr Res. 1992;12:569-582.

109. Masters C. Omega-3 fatty acids and the peroxisome. Mol Cell Biochem. 1996;165:83-93.

110. Pereira C, Li D, Sinclair AJ. The alpha-linolenic acid content of green vegetables commonly available in Australia. Int $J$ Vitam Nutr Res. 2001;71: 223-228.

111. Burdge GC, Jones AE, Wooton SA. Eicosapentaenoic and docosapentaenoic acids are the principal products of alpha-linolenic acid metabolism in young men. Br J Nutr. 2002;88:355-363.

112. Appleby PN, Thorogood M, Mann JI, Key TJ. The Oxford Vegetarian Study: An overview. Am J Clin Nutr. 1999;70:525S-531S.

113. Remer $T$, Neubert $A$, Manz F. Increased risk of iodine deficiency with vegetarian nutrition. Br J Nutr. 1999;81:45-49.

114. Hebbelinck $M$, Clarys $P$. Physical growth and development of vegetarian children and adolescents. In: Sabate J, ed. Vegetarian Nutrition. Boca Raton, FI: CRC Press; 2001:173-193.

115. Mangels AR, Messina V. Considerations in planning vegan diets: infants. J Am Diet Assoc. 2001;101:670-677.

116. Sanders TAB, Manning J. The growth and development of vegan children. J Hum Nutr Diet. 1992;5:11-21.

117. Fulton JR, Hutton CW, Stitt KR. Preschool vegetarian children. J Am Diet Assoc. 1980;76:360-365.

118. Neumark-Sztainer D, Story M, Resnick MD, Blum RW. Adolescent vegetarians: A behavioural profile of a school-based population in Minnesota. Arch Pediatr Adolesc Med. 1997;151:833-838.

119. Sabate J, Linsted KD, Harris RD, Johnston PK. Anthropometric parameters of school children with different life-styles. Am J Dis Child. 1990;144: 1159-1163.

120. Ruys J, Hickie JB. Serum cholesterol and triglyceride levels in Australian adolescent vegetarians. Br Med J. 1976;2:87.

121. Krajcovicova-Kudlackova M, Simoncic R, Bederova A, Grancicova E, Megalova T. Influence of vegetarian and mixed nutrition on selected haematological and biochemical parameters in children. Nahrung. 1997;41:311-314. 122. O'Connell JM, Dibley MJ, Sierra J, Wallace B, Marks JS, Yip R. Growth of vegetarian children. The Farm study. Pediatrics. 1989;84:475-481. 
123. Committee on Nutrition, American Academy of Pediatrics. Pediatric Nutrition Handbook. 4th ed. Elk Grove Village, IL: AAP; 1998.

124. Allen LH. Zinc and micronutrient supplements for children. Am J Clin Nutr. 1998;68(suppl):495S-498S.

125. Krebs NF. Zinc supplementation during lactation. Am J Clin Nutr. 1998; 68(suppl):509S-512S.

126. Nathan I, Hackett AF, Kirby S. A longitudinal study of the growth of matched pairs of vegetarian and omnivorous children, aged $7-11$ years, in the north-west of England. Eur J Clin Nutr. 1997;51:20-25.

127. van Dusseldorp M, Arts ICW, Bergsma JS, De Jong N, Dagnelie PC, Van Staveren WA. Catch-up growth in children fed a macrobiotic diet in early childhood. J Nutr. 1996;126:2977-2983.

128. Nathan I, Hackett AF, Kirby $S$. The dietary intake of a group of vegetarian children aged 7-11 years compared with matched omnivores. Br J Nutr. 1996;75:533-544.

129. Millward DJ. The nutritional value of plant-based diets in relation to human amino acid and protein requirements. Proc Nutr Soc. 1999;58:249260.

130. Mangels AR. Nutrition management of the vegetarian child. In: NevinFolino N, ed. Pediatric Manual of Clinical Dietetics, 2nd ed. Chicago, IL: American Dietetic Association, 2003.

131. Sabate J, Linsted KD, Harris RD, Sanchez A. Attained height of lactoovo-vegetarian children and adolescents. Eur J Clin Nutr. 1991;45:51-58.

132. Sanchez A, Kissinger DG, Phillips RI. A hypothesis on the etiological role of diet on age of menarch. Med Hypotheses. 1981;7:1339-1345.

133. Kissinger DG, Sanchez $A$. The association of dietary factors with the age of menarche. Nutr Res. 1987;7:471-479.

134. Barr SI. Women's reproductive function. In: Sabate J, ed. Vegetarian Nutrition. Boca Raton, Fl: CRC Press; 2001:221-249.

135. Hebbelinck M, Clarys $P$, De Malsche A. Growth, development, and physical fitness of Flemish vegetarian children, adolescents, and young adults. Am J Clin Nutr. 1999;70(suppl):579S-585S.

136. van Lenthe FJ, Kemper HCG, van Mechelen W. Rapid maturation in adolescence results in greater obesity in adulthood: The Amsterdam Growth and Health Study. Am J Clin Nutr. 1996;64:18-24.

137. Berkey CS, Frazier AL, Gardner JD, Colditz GA. Adolescence and breast carcinoma risk. Cancer. 1999;85:2400-2409.

138. O'Connor AM, Touyz WS, Dunn SM, Beumont PJ. Vegetarianism in anorexia nervosa? A review of 116 consecutive cases. Med J Aust. 1987;147: 540-542.

139. Perry CL, McGuire MT, Newmark-Sztainer D, Story M. Characteristics of vegetarian adolescents in a multiethnic urban population. $J$ Adolesc Health 2001;29:406-416.

140. Martins $Y$, Pliner $P$, O'Connor R. Restrained eating among vegetarians: Does a vegetarian eating style mask concerns about weight? Appetite. 1999; 32:145-154.

141. Barr SI. Vegetarianism and menstrual cycle disturbances: Is there an association? Am J Clin Nutr. 1999;70(suppl):549S-554S.

142. Drake R, Reddy S, Davies J. Nutrient intake during pregnancy and pregnancy outcome of lacto-ovo-vegetarians, fish-eaters and non-vegetarians. Veg Nutr. 1998;2:45-52.

143. Lakin V, Haggarty P, Abramovich DR. Dietary intake and tissue concentrations of fatty acids in omnivore, vegetarian, and diabetic pregnancy. Prost Leuk Ess Fatty Acids. 1998;58:209-220.

144. Sanders TAB, Reddy $S$. The influence of a vegetarian diet on the fatty acid composition of human milk and the essential fatty acid status of the infant. J Pediatr. 1992;120:S71-S77.

145. Hornstra G. Essential fatty acids in mothers and their neonates. Am J Clin Nutr. 2000;71(suppl):1262S-1269S.

146. Marsh AG, Christiansen DK, Sanchez TV, Mickelsen O, Chaffee FL. Nutrient similarities and differences of older lacto-ovo-vegetarian and omnivorous women. Nutr Rep Int. 1989;39:19-24.

147. Brants HAM, Lowik MRH, Westenbrink S, Hulshof KFAM, Kistemaker C. Adequacy of a vegetarian diet at old age (Dutch Nutrition Surveillance System). J Am Coll Nutr. 1990;9:292-302.

148. Campbell WW, Evans WJ. Protein requirements of elderly people. Eur $J$ Clin Nutr. 1996;50(suppl):S180-S183.

149. American Dietetic Association. Nutrition, aging, and the continuum of care-Position of ADA. J Am Diet Assoc. 2000;100:580-595.

150. Larson DE. Vegetarian athletes. In: Rosenbloom CA, ed. Sports Nutrition. A Guide for the Professional Working with Active People, 3rd ed. Chicago, IL: American Dietetic Association, Sports, Cardiovascular, and Wellness Dietetic Practice Group; 2000:405-425.

151. Kaiserauer S, Snyder AC, Sleeper M, Zierath J. Nutritional, physiological, and menstrual status of distance runners. Med Sci Sports Exerc. 1989;21: 120-125.

152. Slavin J, Lutter J, Cushman S. Amenorrhea in vegetarian athletes. Lancet. 1984;1:1974-1975.
153. Key T, Davey G. Prevalence of obesity is low in people who do not eat meat (letter). Br Med J. 1996;313:816-817.

154. Key TJ, Fraser GE, Thorogood M, Appleby PN, Beral V, Reeves G, Burr ML, Chang-Claude J, Frentzel-Beyme R, Kuzma JW, Mann J, McPherson K. Mortality in vegetarians and nonvegetarians: Detailed findings from a collaborative analysis of 5 prospective studies. Am J Clin Nutr. 1999;70:516S-524S. 155. Phillips RL, Lemon FR, Beeson L, Kuzma JW. Coronary heart disease mortality among Seventh-Day Adventists with differing dietary habits: A preliminary report. Am J Clin Nutr. 1978;31:S191-S198.

156. Resnicow K, Barone J, Engle A, Miller S, Haley NJ, Fleming D, Wynder E. Diet and serum lipids in vegan vegetarians: A model for risk reduction. $J \mathrm{Am}$ Diet Assoc. 1991;91:447-453.

157. Sacks FM, Castelli WP, Donner A, Kass EH. Plasma lipids and lipoproteins in vegetarians and controls. N Engl J Med. 1975;292:1148-1151.

158. Thorogood M, McPherson K, Mann J. Relationship of body mass index, weight, and height to plasma lipid levels in people with different diets in Britain. Community Med. 1989;11:230-233.

159. Mosca L, Grundy SM, Judelson D, King K, Limacher M, Oparil S, Pasternak R, Pearson TA, Redberg RF, Smith SC, Winston M, Zinberg S. AHAVACC Scientific Statement: Consensus Panel Statement: Guide to Preventive Cardiology for Women. Circulation. 1999;99:2480-2484.

160. Brown L, Rosner B, Willett WW, Sacks FM. Cholesterol-lowering effects of dietary fiber: A meta-analysis. Am J Clin Nutr. 1999;69:30-42.

161. Smit E, Nieto FJ, Crespo CJ. Blood cholesterol and apolipoprotein B levels in relation to intakes of animal and plant proteins in US adults. Br J Nutr. 1999;82:193-201.

162. Anderson JW, Johnstone BM, Cook-Newell ME. Meta-analysis of the effects of soy protein intake on serum lipids. N Engl J Med. 1995;333:276282.

163. Wiseman H, O'Reilly JD, Adlercreutz H, Mallet Al, Bowey EA, Rowland IR, Sanders TA. Isoflavone phytoestrogens consumed in soy decrease $F(2)-$ isoprostane concentrations and increase resistance of low-density lipoprotein to oxidation in humans. Am J Clin Nutr. 2000;72:395-400.

164. Simons PC, Algra A, Bots ML, Grobbee DE, van der Graaf Y. Common carotid intima-media thickness and arterial stiffness: Indicators of cardiovascular risk in high-risk patients. The SMART Study (Secondary Manifestations of ARTerial disease). Circulation. 1999;100:951-957.

165. Dubey RK, Gillespie DG, Imthurn B, Rosselli M, Jackson EK, Keller PJ. Phytoestrogens inhibit growth and MAP kinase activity in human aortic smooth muscle cells. Hypertension. 1999;33:177-182.

166. Chan MM, Ho CT, Huang HI. Effects of three dietary phytochemicals from tea, rosemary, and turmeric on inflammation-induced nitrite production. Cancer Lett. 1995;96:23-29.

167. Lin CL, Fang TC, Gueng MK. Vascular dilatory functions of ovo-lactovegetarians compared with omnivores. Atherosclerosis. 2001;158:247-251.

168. Mann NJ, Li D, Sinclair AJ, Dudman NP, Guo XW, Elsworth GR, Wilson AK, Kelly FD. The effect of diet on plasma homocysteine concentrations in healthy male subjects. Eur J Clin Nutr. 1999;53:895-899.

169. Krajcovicova-Kudlackova M, Blazicek P, Kopcova J, Bederova A, Babinska K. Homocysteine levels in vegetarians versus omnivores. Ann Nutr Metab. 2000;44:135-138.

170. Hung CJ, Huang PC, Lu SC, Li YH, Huang HB, Lin BF, Chang SJ, Chou HF. Plasma homocysteine levels in Taiwanese vegetarians are higher than those of omnivores. J Nutr. 2002;132:152-158.

171. Bissoli L, DiFrancesco V, Ballarin A, Mandragona R, Trespidi R, Brocco G, Caruso B, Bosello O, Zamboni M. Effect of vegetarian diet on homocysteine levels. Ann Nutr Metab. 2002;46:73-79.

172. Houghton LA, Green TJ, Donovan UM, Gibson RS, Stephen AM, O'Connor DL. Association between dietary fiber intake and the folate status of a group of female adolescents. Am J Clin Nutr. 1997;66:1414-1421.

173. Mezzano D, Kosiel K, Martinez C, Cuevas A, Panes O, Aranda E, Strobel P, Perez DD, Pereira J, Rozowski J, Leighton F. Cardiovascular risk factors in vegetarians. Normalization of hyperhomocysteinemia with vitamin $\mathrm{B}(12)$ and reduction of platelet aggregation with n-3 fatty acids. Thromb Res. 2000;100: 153-160.

174. Hypertension Detection and Follow-up Program Cooperative Group. Five-year findings of the hypertension detection and follow-up program. I. Reduction in mortality of person with high blood pressure, including mild hypertension. J Am Med Assoc. 1979;242:2562-2571.

175. Ophir O, Peer G, Gilad J, Blum M, Aviram A. Low blood pressure in vegetarians: The possible roles of potassium. Am J Clin Nutr. 1983;37:755762.

176. Melby CL, Hyner GC, Zoog B. Blood pressure in vegetarians and non-vegetarians: A cross-sectional analysis. Nutr Res. 1985;5:1077-1082.

177. Sciarrone SE, Strahan MT, Beilin LJ, Burke V, Rogers $P$, Rouse IL. Biochemical and neurohormonal responses to the introduction of a lactoovovegetarian diet. J Hypertens. 1993;11:849-860.

178. Rouse IL, Beilin LJ, Mahoney DP, Margetts BM, Armstrong BK, Record 
SJ, Vandongen R, Barden A. Nutrient intake, blood pressure, serum and urinary prostaglandins and serum thromboxane B2 in a controlled trial with a lacto-ovo-vegetarian diet. J Hypertens. 1986;4:241-250.

179. Rouse IL, Armstrong BK, Beilin LJ. The relationship of blood pressure to diet and lifestyle in two religious populations. J Hypertens. 1983;1:65-71. 180. Prescott SL, Jenner DA, Beilin LJ, Margetts BM, Vandongen R. A randomized controlled trial of the effect on blood pressure of dietary nonmeat protein versus meat protein in normotensive omnivores. Clin Sci. 1988; 74:665-672.

181. Brussard JH, Van Raaij JM, Stasse-Wolthuis M, Katan MB, Hautvast JG. Blood pressure and diet in normotensive volunteers: Absence of an effect of dietary fiber, protein, or fat. Am J Clin Nutr. 1981;34:2023-2029.

182. Sacks FM, Rouse IL, Stampfer MJ, Bishop LM, Lenherr CF, Walther RJ. Effect of dietary fats and carbohydrate on blood pressure of mildly hypertensive patients. Hypertension. 1987;10:452-460.

183. Margetts BM, Beilin LJ, Vandongen R, Armstrong BK. A randomized controlled trial of the effect of dietary fiber on blood pressure. Clin Sci. 1987;72:343-350.

184. Rouse IL, Beilin LJ, Armstrong BK, Vandongen R. Blood pressure lowering effect of a vegetarian diet: Controlled trial in normotensive subjects. Lancet. 1983;1:5-10.

185. Landsberg L, Young JB. The role of the sympathetic nervous system and catecholamines in the regulation of energy metabolism. Am J Clin Nutr. 1983;38:1018-1024.

186. Sacks FM, Kass EH. Low blood pressure in vegetarians: Effects of specific foods and nutrients. Am J Clin Nutr. 1988;48:795-800.

187. American Diabetes Association Position Statement: Evidence-based nutrition principles and recommendations for the treatment and prevention of diabetes and related complications. J Am Diet Assoc. 2002;102:109-118.

188. Snowdon DA, Phillips RL. Does a vegetarian diet reduce the occurrence of diabetes? Am J Public Health. 1985;75:507-512.

189. Lipkin M, Uehara K, Winawer S, Sanchez A, Bauer C, Phillips R, Lynch HT, Blattner WA, Fraumeni JF Jr. Seventh-day Adventist vegetarians have a quiescent proliferative activity in colonic mucosa. Cancer Lett. 1985;26:139144.

190. Allen NE, Appleby PN, Davey GK, Key TJ. Hormones and diet: Low insulin-like growth factor-I but normal bioavailable androgens in vegan men. Br J Cancer. 2000;83:95-97.

191. Giovannucci E, Rimm EB, Wolk A, Ascherio A, Stampher MJ, Colditz GA, Willett WC. Calcium and fructose intake in relation to risk of prostate cancer. Cancer Res. 1998;58:442-447.

192. Chan JM, Giovannucci E, Andersson SO, Yuen J, Adami HO, Wolk A. Dairy products, calcium, phosphorus, vitamin D, and risk of prostate cancer. Cancer Causes Control. 1998;9:559-566.

193. Chan JM, Stampfer MJ, Ma J, Gann PH, Garziano JM, Giovannucci EL. Dairy products, calcium, and prostate cancer risk in the Physician's Health Study. Am J Clin Nutr. 2001;74:549-554.

194. Tavani A, Gallus S, Franceschi S, La Vecchia C. Calcium, dairy products, and the risk of prostate cancer. Prostate. 2001;48:118-121.

195. Missmer SA, Smith-Warner SA, Spiegelman D, Yaun SS, Adami HO, Beeson WL, van der Brandt PA, Fraser GE, Frendenheim JL, Goldbohm RA, Graham S, Kushi LH, Miller AB, Potter JD, Rohan TE, Speizer FE, Toniolo P, Willet WC, Wolk A, Zeleniuch-Jacquotte A, Hunter DJ. Meat and dairy food consumption and breast cancer: a pooled analysis of cohort studies. Int $J$ Epidemiol. 2002;31:78-85.

196. Butrum RR, Clifford CK, Lanza E. National Cancer Institute dietary guidelines: rationale. Am J Clin Nutr. 1988;48:888-895.

197. Barbosa JC, Shultz TD, Filley SJ, Nieman DC. The relationship among adiposity, diet, and hormone concentrations in vegetarian and nonvegetarian postmenopausal women. Am J Clin Nutr. 1990;51:798-803.

198. Howe GR, Benito E, Castellato R, Cornee J, Esteve J, Gallagher RP, Iscovich JM, Deng-ao J, Kaaks R, Kune GA. Dietary intake of fiber and decreased risk of cancers of the colon and rectum:evidence from the combined analysis of 13 case-control studies. J Nat Canc Inst. 1992;84:18871896.

199. Alberts DS, Martinez ME, Roe DJ, Guillen-Rodriguez JM, Marshall JR, van Leeuwen JB, Reid ME, Ritenbaugh C, Vargas PA, Bhattacharyya AB, Earnest DL, Sampliner RE. Lack of effect of a high-fiber cereal supplement on the recurrence of colorectal adenomas. Phoenix Colon Cancer Prevention Physicians' Network. N Engl J Med. 2000;342:1156-1162.

200. van Faassen A, Hazen JM, van den Brandt PA, van den Bogaard AE, Hermus RJ, Janknegt RA. Bile acids and $\mathrm{pH}$ values in total feces and in fecal water from habitually omnivorous and vegetarian subjects. Am J Clin Nutr. 1993;58:917-922.

201. Finegold SM, Sutter VL, Sugihara PT, Elder HA, Lehmann SM, Phillips RL. Fecal microbial flora in Seventh Day Adventist populations and control subjects. Am J Clin Nutr. 1977;30:1781-1792.
202. Davies GJ, Crowder M, Reid B, Dickerson JW. Bowel function measurements of individuals with different eating patterns. Gut. 1986;27:164-169. 203. Nader CJ, Potter JD, Weller RA. Diet and DNA-modifying activity in human fecal extracts. Nutr Rep Int. 1981;23:113-117.

204. Sesink AL, Termont DS, Kleibeuker JH, van der Meer R. Red meat and colon cancer: The cytotoxic and hyperproliferative effects of dietary heme. Cancer Res. 1999;59:5704-5709.

205. Griffiths K. Estrogens and prostatic disease. International Prostate Health Council Study Group. Prostate. 2000;45:87-100.

206. Messina MJ, Loprinzi CL. Soy for breast cancer survivors: A critical review of the literature. J Nutr. 2001;131:3095S-3108S.

207. Linkswiler HM, Zemel MB, Hegsted M, Schuette S. Protein induced hypercalciuria. Fed Proc. 1981;40:2429-2433.

208. Kerstetter JE, Allen LH. Dietary protein increases urinary calcium. J Nutr. 1990;120:134-136.

209. Itoh $R$, Nishiyama $N$, Suyama $Y$. Dietary protein intake and urinary excretion of calcium: A cross-sectional study in a healthy Japanese population. Am J Clin Nutr. 1998;67:438-444.

210. Kunkel ME, Beauchene RE. Protein intake and urinary excretion of protein-derived metabolites in aging female vegetarians and nonvegetarians. J Am Coll Nutr. 1991;10:308-314.

211. Sellmeyer DE, Stone KL, Sebastian A, Cummings SR. A high ratio of dietary animal to vegetable protein increases the rate of bone loss and the risk of fracture in postmenopausal women. Am J Clin Nutr. 2001;73:118-122.

212. Kerstetter JE, Svastisalee CM, Caseria DM, Mitnick ME, Insogna KL. A threshold for low-protein diet-induced elevations in parathyroid hormone. Am J Clin Nutr. 2000;72:168-173.

213. Marsh AG, Sanchez TV, Michelsen O, Chaffee FL, Fagal SM. Vegetarian lifestyle and bone mineral density. Am J Clin Nutr. 1988;48:837-841.

214. Chiu JF, Lan SJ, Yang CY, Wang PW, Yao WJ, Su LH, Hsieh CC. Long term vegetarian diet and bone mineral density in postmenopausal Taiwanese women. Calcif Tissue Int. 1997;60:245-249.

215. Hu JF, Zhao XH, Jia JB, Parpia B, Campbell TC. Dietary calcium and bone density among middle aged and elderly women in China. Am J Clin Nutr. 1993;58:219-227.

216. Outila TA, Karkkainen MU, Seppanen RH, Lamberg-Allardt CJ. Dietary intake of vitamin D in premenopausal, healthy vegans was insufficient to maintain concentrations of serum 25-hydroxyvitamin D and intact parathyroid hormone within normal ranges during the winter in Finland. J Am Diet Assoc. 2000;100:434-441.

217. Outila TA, Lamberg-Allardt CJ. Ergocalciferol supplementation may positively affect lumbar spine bone mineral density of vegans (letter). J Am Diet Assoc. 2000;100:629.

218. Lamberg-Allardt C, Karkkainen M, Seppanen R, Bistrom H. Low serum 25-hydroxyvitamin D concentrations and secondary hyperparathyroidism in middle-aged white strict vegetarians. Am J Clin Nutr. 1993;58:684-689.

219. Arjmandi BH, Smith BJ. Soy isoflavones' osteoprotective role in postmenopausal women: Mechanism of action. J Nutr Biochem. 2002;13:130137.

220. Bosch JP, Saccaggi A, Lauer A, Ronco C, Belledonne M, Glabman S. Renal functional reserve in humans. Effect of protein intake on glomerular filtration rate. Am J Med. 1983;75:943-950.

221. Wiseman MJ, Hunt R, Goodwin A, Gross JL, Keen H, Viberti GC. Dietary composition and renal function in healthy subjects. Nephron. 1987;46:37-42. 222. Kontessis $P$, Jones $S$, Dodds $R$, Trevisan $R$, Nosadini R, Fioretto $P$, Borsato M, Sacerdoti D, Viberti G. Renal, metabolic and hormonal responses to ingestion of animal and vegetable proteins. Kidney Int. 1990;38:136-144. 223. Kontessis PA, Bossinakou I, Sarika L, Iliopoulou E, Papantoniou A, Trevisan R, Roussi D, Stipsanelli K, Grigorakis S, Souvatzoglou A. Renal, metabolic, and hormonal responses to proteins of different origin in normotensive, nonproteinuric type 1 diabetic patients. Diabetes Care. 1995;18:1233. 224. Geim P, Beeson WL, Fraser GE. The incidence of dementia and intake of animal products: Preliminary findings from the Adventist Health Study. Neuroepidemiology. 1993;12:28-36.

225. Riedel WJ, Jorissen BL. Nutrients, age and cognitive function. Curr Opin Clin Nutr Metab Care. 1998;1:579-585.

226. Olson DA. Association of vitamin $E$ and $C$ supplement use with cognitive function and dementia in elderly men. Neurology. 2000;55:901-902.

227. Ross GW, Petrovitch H, White LR, Masaki KH, Li CY, Curb JD, Yano K, Rodriguez BL, Foley DJ, Blanchette PL, Havlik R. Characterization of risk factors for vascular dementia: The Honolulu-Asia Aging Study. Neurology. 1999;53:337-343.

228. Wolozin B, Kellman W, Ruosseau P, Celesia GG, Siegel G. Decreased prevalence of Alzheimer's Disease associated with 3-hydrozy-3-methylglutaryl coenzyme A reductase inhibitors. Arch Neurol. 2000;57:1439-1443.

229. Snowdon DA, Tully CL, Smith CD, Riley KP, Markesbery WR. Serum folate and the severity of atrophy of the neocortex in Alzheimer's disease: Findings from the Nun Study. Am J Clin Nutr. 2000;71:993-998. 
230. Nourhashemi F, Gillette-Guyonnet S, Andrieu S, Ghisolfi A, Ousset PJ, Grandjean H, Grand A, Pous J, Vellas B, Albarede JL. Alzheimer's Disease: Protective factors. Am J Clin Nutr. 2000;71:643S-649S.

231. Nilsson K, Gustafson L, Hultberg B. The plasma homocysteine concentration is better than that of serum methylmalonic acid as a marker for sociopsychological performance in a psychogeriatric population. Clin Chem. 2000;46:691-696.

232. Delport R. Hyperhomocyst(e)inemia: Related vitamins and dementias. $J$ Nutr Health Aging. 2000;4:195-196.

233. White LR, Petrovitch H, Ross GW, Masaki K, Hardman J, Nelson J, Davis $\mathrm{D}$, Markesbery W. Brain aging and midlife tofu consumption. J Am Coll Nutr. 2000;19:242-255.

234. Rice MM, Graves AB, McCurry SM, Gibbons L, Bowen J, McCormick W, Larson EB. Tofu consumption and cognition in older Japanese American men and women. J Nutr. 2000;130(suppl 3):676S.

235. Gear JS, Ware A, Fursdon P, Mann JI, Nolan DJ, Broadribb AJ, Vessey MP. Symptomless diverticular disease and intake of dietary fibre. Lancet. 1979;1:511-514.

236. Aldoori WH, Giovannucci EL, Rimm EB, Wing AL, Trichopoulos DV, Willett WC, A prospective study of diet and the risk of symptomatic diverticular disease in men. Am J Clin Nutr 1994;60:757-764.

237. Heaton KW. Diet and diverticulosis: New leads (editorial). Gut. 1985;26: 541-543.

238. Pixley F, Wilson D, McPherson K, Mann J. Effect of vegetarianism on development of gall stones in women. Br Med J (Clin Res Ed). 1985:291:1112.

239. Kjeldsen-Kragh J. Rheumatoid arthritis treated with vegetarian diets. Am J Clin Nutr. 1999;70:594S-600S.

240. Muller H, de Toledo FW, Resch KL. Fasting followed by vegetarian diet in patients with rheumatoid arthritis: A systematic review. Scand J Rheumatol. 2001;30:1-10.

241. Donaldson MS, Speight N, Loomis S. Fibromyalgia syndrome improved using a mostly raw vegetarian diet: An Observational study. BMC Complement Altern Med. 2001;1:7.

242. Tanaka $T$, Kouda $K$, Kotani M, Takeuchi $A$, Tabei $T$, Masamoto $Y$, Nakamura H, Takigawa M, Suemura M, Takeuchi H, Kouda M. Vegetarian diet ameliorates symptoms of atopic dermatitis through reduction of the number of peripheral eosinophisl and of PGE2 synthesis by monocytes. J Physiol Anthropol Appl Human Sci. 2001;20:353-361.

243. Special Supplemental Nutrition Program for Women, Infants and Children (1-1-02 edition). Federal Register, Code of Federal Regulations, 7CFR, Part 246; 2002.

244. Canada Prenatal Nutrition Program. Projects directory online. Available at: www.ssjs.hc-sc.gc.ca/cpnp. Accessed February 10, 2003.

245. Modification of the "Vegetable Protein Products" requirements for the National School Lunch Program, School Breakfast Program, Summer Food Service Program and Child And Adult Care Food Program. (7 CFR 210, 215, 220, 225, 226) Federal Register. March 9, 2000;65:12429-12442.

246. US Department of Agriculture. Menu planning in the National School Lunch Program. Available at: http://www.fns.usda.gov/cnd/MenuPlanning/ menu.planning.approaches.for.lunches.doc. Accessed February 10, 2003.

247. US Department of Agriculture. A Toolkit for Healthy School Meals: Recipes and Training Materials. Available at: http://www.nal.usda.gov/fnic/ schoolmeals/Training/train.html. Accessed February 10, 2003.

248. Canadian Living Foundation. Breakfast for learning. Available at: www. breakfastforlearning.ca. Accessed February 10, 2003.

249. Administration on Aging. The Elderly Nutrition Program. Available at: http://www.aoa.gov/factsheets/enp.html. Accessed February 10, 2003.

250. The Vegetarian Resource Group. 4-week Vegetarian Menu Set for Meals on Wheels Sites. Available at: http://www.vrg.org/fsupdate/fsu974/ fsu974menu.htm. Accessed February 10, 2003.

251. Havala S, Abate T. The National Meals on Wheels Foundation Vegetarian Initiative: A unique collaboration. J Nutr Elderly. 1997;17:45-50.

252. Docket T-1487-99, September 29, 2000 and January 21, 2002, between Jack Maurice and Attorney General of Canada, Federal Court of Canada Trial Division.

253. Ogden A, Rebein P. Do Prison Inmates Have a Right to Vegetarian Meals? Vegetarian Journal Mar/Apr 2001. Available at: http://www.vrg.org/ journal/vj2001mar/2001marprison.htm. Accessed February 10, 2003.

254. US Department of Defense. DOD Combat Feeding Program. Available at: http://www.sbccom.army.mil/programs/food/. Accessed February 10, 2003. 255. Department of National Defence. Food Services Direction \& Guidance Manual, Chapter 2. Ottawa, ON, Canada; 2003.

256. Canadian Forces Food Services. Maple Leaf. 2000; Volume 3, Issue 39, page 14-15 and Issue 37, pages 14-15. Available at: www.forces.gc.ca/site/ community/mapleleaf/html_files/html_view_e.asp. Accessed February 10, 2003.
ADA Position adopted by the House of Delegates on October 18, 1987, and reaffirmed on September 12, 1992, September 6, 1996 and June 22, 2000. This position was developed collaboratively between the American Dietetic Association and Dietitians of Canada. This position will be in effect until December 31, 2007. ADA authorizes republication of the position statement/support paper, in its entirety, provided full and proper credit is given. Requests to use portions of the position must be directed to ADA Headquarters at 800/877-1600, ext 4835, or ppapers@eatright.org Recognition is given to the following for their contributions:

Authors:

Ann Reed Mangels, PhD, RD, FADA (The Vegetarian Resource Group, Baltimore, MD);

Virginia Messina, MPH, RD (Nutrition Matters, Inc., Port Townsend, WA);

Vesanto Melina, MS, RD (NUTRISPEAK.COM, Langley, BC, Canada).

American Dietetic Association Reviewers:

Judith G. Dausch, PhD, RD (American Dietetic Association Government Relations, Washington, DC);

Sharon Denny, MS, RD (American Dietetic Association Knowledge Center, Chicago, IL);

Elaine K. Fleming, MPH, RD (Loma Linda University, Loma Linda, CA);

Food and Culinary Professionals DPG (Robin Kline, MS, RD, CCP, Savvy Food Communications, Des Moines, IA; Sylvia E. Klinger, MS, RD, Hispanic Food Communications, La Grange, IL);

D. Enette Larson-Meyer, PhD, RD (Pennington Biomedical Research Center, Baton Rouge, LA);

Nutrition in Complementary Care DPG (Dennis Gordon, MEd, RD, Saint Joseph Mercy Health System, Ann Arbor, MI; Rita Batheja, MS, RD, Private Practice, Long Island, NY);

Pediatric Nutrition DPG (Maria Hanna, MS, RD, Children's Hospital of Philadelphia, Philadelphia, PA; Cristine M. Trahms, MS, RD, FADA, University of Washington, Seattle, WA; Tamara Schryver, MS, RD, University of Minnesota, St. Paul, MN);

Sports, Cardiovascular, and Wellness Nutritionist DPG (Gita B. Patel, MS, RD, Alice Peck Day Memorial Hospital, Lebanon, NH; Pamela J. Edwards, MS, RD, University of Nebraska Lincoln, Lincoln, NE);

Vegetarian Nutrition DPG (Winston J. Craig, PhD, RD, Andrews University, Berrien Springs, MI; Catherine Conway, MS, RD, Private Practice, New York, NY);

Women and Reproductive Nutrition DPG (Judith B. Roepke, $\mathrm{PhD}, \mathrm{RD}$, Ball State University, Muncie, IN).

Dietitians of Canada Reviewers:

Karen Birkenhead, RD, (Group Health Centre, Sault Ste Marie, ON);

Samara Felesky Hunt (Consulting Dietitian, Calgary AB);

Susie Langley MS, RD (Nutrition Consultant in Private Practice, Toronto, ON);

Pam Lynch, MHE, RD (Nutrition Counselling Services, Halifax, NS);

Shefali Raja (Vancouver Coastal Health Authority, Vancouver BC);

Marilyn Rabin PDt (Douglas Hospital, Verdun, PQ);

Laura Toews, RD (St. Boniface General Hospital, Winnipeg, $\mathrm{MB})$.

Members of the Association Positions Committee Workgroup:

Barbara Emison Gaffield, MS, RD (chair), Barbara Baron, MS, RD; Suzanne Havala Hobbs, DrPH, RD, FADA (content advisor). 